Florida International University FIU Digital Commons

\title{
Buddhism and its relation to women and prostitution in Thai society
}

Sandra Avila

Florida International University

DOI: $10.25148 /$ etd.FI14032376

Follow this and additional works at: https://digitalcommons.fiu.edu/etd

Part of the Religion Commons

\section{Recommended Citation}

Avila, Sandra, "Buddhism and its relation to women and prostitution in Thai society" (2008). FIU Electronic Theses and Dissertations. 1343.

https://digitalcommons.fiu.edu/etd/1343

This work is brought to you for free and open access by the University Graduate School at FIU Digital Commons. It has been accepted for inclusion in FIU Electronic Theses and Dissertations by an authorized administrator of FIU Digital Commons. For more information, please contact dcc@fiu.edu. 


\section{FLORIDA INTERNATIONAL UNIVERSITY}

Miami, Florida

\section{BUDDHISM AND ITS RELATION TO WOMEN AND PROSTITUTION IN THAI SOCIETY}

A thesis submitted in partial fulfillment of the

requirements for the degree of

MASTER OF ARTS

in

RELIGIOUS STUDIES

by

Sandra Avila

2008 
To: Dean Kenneth Furton

College of Arts and Sciences

This thesis, written by Sandra Avila, and entitled Buddhism and its Relation to Women and Prostitution in Thai Society, having been approved in respect to style and intellectual content, is referred to you for judgment.

We have read this thesis and recommend that it be approved.

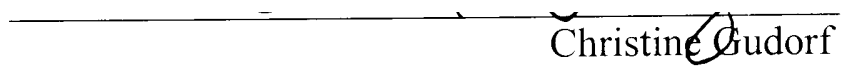

Nathan Katz

Steven Heine, Major Professor

Date of Defense: March 26, 2008

The thesis of Sandra Avila is approved.

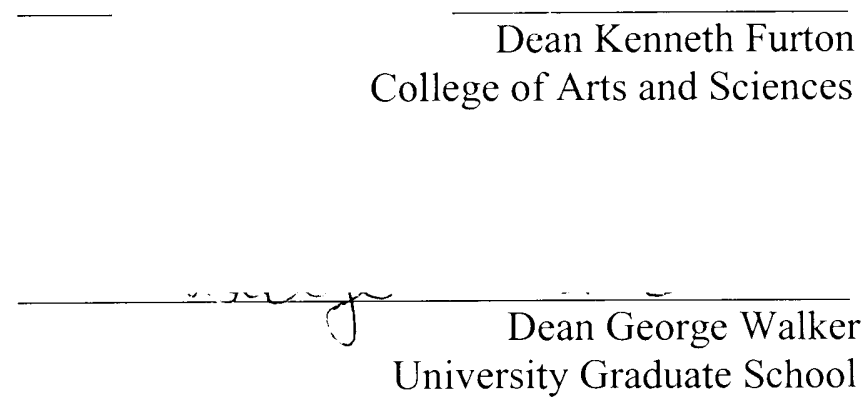

Florida International University, 2008 


\section{DEDICATION}

I dedicate this thesis first and foremost, to my parents, because if it wasn't for their unconditional love and encouragement I would not be where I am today. Thank you for never questioning why I have spent so many years at the university. But also, the love and respect I have found in my partner Abiu Gonzalez cannot go unstated. Thank you for your continued kindness and support, though most importantly your selfless heart. I know that with you at my side I will continue to grow academically and personally. 


\section{ACKNOWLEDGMENTS}

I thank my major professor, Dr. Steven Heine, for his continued assistance and collaboration as a mentor and professor the past six years. The Fu Foundation Scholarship offered through the Institute for Asian Studies gave me my first glimpse at “Amazing Thailand.” I appreciate your guidance throughout my post-undergraduate and graduate study at Florida International University and also for the Institute's continuing financial support. Dr. Christine Gudorf cannot go unmentioned as her consistent rearing has provided me with a study abroad opportunity to Indonesia, a paper presentation at the American Academy of Religion, and funding to several conferences both in and outside the United States. Thank you for pushing me, it has proven successful. I also thank Dr. Nathan Katz who has provided me with an excellent background in Indian Buddhism and culture. I have learned a great deal from your exuberant lectures and enthusiastic teaching. Thank you all for your attentiveness to this MA thesis. 


\section{ABSTRACT OF THE THESIS \\ BUDDHISM AND ITS RELATION TO WOMEN AND PROSTITUTION IN THAI \\ SOCIETY}

by

Sandra Avila

Florida International University, 2008

Miami, Florida

Professor Steven Heine, Major Professor

The purpose of this research was to investigate how Buddhism affects the status of Thai women by (1) not directly addressing concerns regarding the sex trade industry, (2) not allowing for the legitimation of a bhikkhuni sangha (community of higher ordained women), and (3) denying mae chis (5-9 precept nuns) access to education and other privileges.

The study is significant from the standpoint of public health since there is a high rate of HIV/AIDS infection in Thailand, and also in regard to human rights because of the growing international interest in women's rights issues. This study is based on a review of key literature on the topic, along with observations and on-the-ground accounts of Thai Buddhism from travel opportunities to the country in recent years.

The findings suggest that Buddhism contributes to the low status of women by defining how they are viewed based on Buddhist scripture and traditional Thai culture and by systematically failing to provide the same religious outlets for women that men are allowed. 


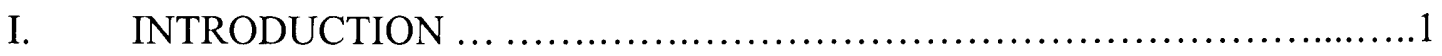

Background ...................................................................

Defining the Terms .......................................................

II. GENDER AND RELIGION IN THAILAND ...........................11

Women's Role in Society ..............................................11

Buddhism and the State ............................................ 19

III. THE DYNAMICS OF THE SEX TRADE IN THAILAND …..............26

Historical Reflections ................................................26

The Thai Economic Boom ...........................................29

Human Rights and HIV/AIDS ........................................ 32

The Modern Perspective and Prostitution Law ............................37

IV. BUDDHISM'S CONNECTON TO THE SEX TRADE $\ldots \ldots \ldots \ldots \ldots \ldots \ldots . \ldots . \ldots . \ldots . \ldots 42$

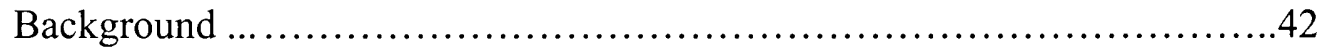

Women and Thai Buddhism . ............................................51

The Thai Concept of "Merit-Making" ..................................62

V. THE THAI MAE CHI POSITION ....................................68

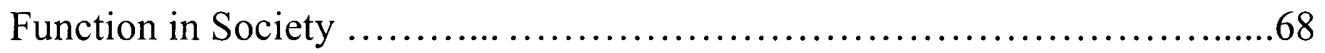

Recent Achievements and Goals for the Future ...........................71

The Thammacarini Witthaya School ...................................76

VI. THE BHIKKHUNI STRUGGLE IN THAILAND ........................79

The Lack of a Bhikkhuni Sangha ............................................79

Three Waves of Bhikkhuni Activism in Thailand ...........................84

Current Strategy and Competition with the Mae chi Movement ................91

Conclusions......................................................... 94

REFERENCES ......................................................... 97 


\section{CHAPTER ONE \\ INTRODUCTION}

\section{Background}

In Thailand today, the status of women in Buddhism is a controversial topic that affects the religious practice as well as the religious institution. However, it also includes broader social and political issues. By Thai social standards, women of all classes and professions are limited in the areas of spiritual achievement, education, and social respect because they are viewed as less significant than their male counterparts. While modernity has begun to transform the attitudes of the highly educated and prosperous through formal schooling, cultural exchange, and economic development, the process of general social change regarding gender roles is still moving slowly. It is because of this bias that modern Thai women have not been able to achieve religious equality within the dominant Theravada Buddhist religious system. ${ }^{1}$

The problems Thai women suffer are not limited to their second-rate role in the monastic tradition, as Thai women historically were denied access to full Buddhist ordination. A bigger problem is derived from the Thai Buddhist faith and its religious and social definition of the attainment of "merit" (puñna). The role merit plays in supporting and persuading young girls to take up a life of prostitution as an act of sacrifice for their family is a social problem of Buddhism in Thailand. The accumulation of merit is viewed as important for the lay Buddhist's religious expression, as it is an indicator of one's future rebirth. A second Buddhist factor involves the sangha (Buddhist community)

\footnotetext{
${ }^{1}$ Thai women have attempted to attain religious equality through the bhikkhuni (fully ordained female monk) path since the 1920s. They have been unsuccessful until this day.
} 
turning a blind eye to the growth and continued acceptance of prostitution. Prostitution is illegal in Thailand, but the government does little to eradicate it, or even, control it. Little is done about the sex trade industry because it is economically profitable and since it is linked to the country's main source of foreign dollars: tourism. The Thai Buddhist sangha enjoys a symbiotic relationship with the government, as Thailand's government regulates and supports Buddhist institutions. The monarch himself must be Buddhist as a way of enforcing and sustaining the Buddhist religion in the kingdom. Buddhism also lacks social concern regarding the sex trade, since it does not speak out in opposition to it. Perhaps this is due to Buddhism's inherent preoccupation with other-worldliness, making one less aware of what is happening in the material world. ${ }^{2}$

Issues regarding the introduction of a Bhikkhuni Sangha (monastic female order) ${ }^{3}$ or the elevation of status for the Thai mae chi (five to nine-precept nun), are matters which involve the government as well as the religious authoritative body. The lack of equal treatment for ordained women in Thailand translates on the social level to Buddhist women being viewed very differently than men in their lesser ability to achieve nibbāna (enlightenment). This further impacts and affects their inferior status in other areas of Thai cultural life. Thai men, in contrast, are granted temporary ordination as Buddhist monks, allowing them to come in and out of the robes several times in their lives if desired. Some scholars conclude that women are viewed as a hindrance to the male sangha because the monks are not necessarily trained to renounce and withstand worldly

\footnotetext{
${ }^{2}$ In Buddhism, the other-world or "other-shore" is considered enlightenment or nibbāna.

${ }^{3}$ Historically, Thailand never received the Bhikkhuni Sangha transmission from Sri Lanka as it made its journey east to China.
} 
pleasure, within the Thai tradition, since temporary ordination in Thailand is a popular choice. ${ }^{4}$ Here we see how women are undermined and depicted as impediments to spiritual growth and salvation.

Another way in which the Buddhist male-dominated sangha is involved in discrimination, is that they silently stand aside as the money being earned by female sex trade workers is brought to their temples as offerings for the receipt of Buddhist puñna. The money brought to the Buddhist temples was respectively handed from sex trade worker to their parents as an accepted form of filial piety. ${ }^{5}$ No comment or question is made by the sangha, which depends on the laity for its continued livelihood. Thus, the sangha indirectly contributes to the problematic process through the condition and acceptance of prostitution.

This work attempts to show how Buddhism in Thailand contributes to the inferior status of women by defining how they are to be viewed and also by not providing the same religious outlets for them that men are granted. Buddhism is seen as indirectly encouraging prostitution by overlooking women's lack of options and not addressing their immediate concerns. The sex trade in Thailand is both illegal and highly corrupt.

\footnotetext{
${ }^{4}$ In Thailand, monks are not allowed to touch or be alone with women for fear they may be enticed and led to unwholesome acts. This is a one way to look at the Buddhist Vinaya, as the Thai tradition pays strict attention to it; they are often considered to be extreme in its handling of the precept. Also, since the Thai style of ordaining is not always for one's entire life, some scholars are led to believe it is tainted with issues of this-worldliness. Other Buddhist countries do not allow temporary ordination and often look down upon the tradition in Thailand.

${ }^{5}$ The Confucius concept of filial piety is seen in a similar view to the Thai Theravada Buddhist idea of merit. Merit (puñña) can be generated by attending Buddhist temples and providing food, service or monetary donations to the sangha, which to this day in Thailand consists solely of males.
} 
Many poor, rural young girls are stolen from villages and sent to Bangkok to serve as sex slaves. Some children are even trafficked across borders to fulfill the roles of prostitutes in Asia and elsewhere. I will show how prostitution in Thailand is intertwined with the Thai bhikkhuni and mae chi movements, since one motivation for many attempting to advance women's religious rights in Thailand is to dramatically decrease the number of female sex trade workers. The goal is to allow all social classes access to free education, provided through the sangha, that could offer a direct outlet to attaining nibbāna. This would also provide women with a better social outlet than the degrading work conditions of prostitution. My analysis will be based in part on on-the-ground observations and materials from travel to Thailand during the summers of 2004 and 2005, as well as an examination of qualitative research by various scholars in one or more of the three areas of interest: the prostitution issue, the status of mae chi, and the bhikkhuni alternative.

The acceptance of prostitution and the economics of the sex trade industry are intimately linked to the struggle of Buddhist women to attain equal rights within the Theravada Buddhist hierarchy of Thailand. Many female as well as male Thai scholars from fields such as economics, philosophy, political science, and religious studies are attempting to create awareness regarding the intricate connections which exist in Thailand today concerning this issue. Some of them suggest that it is possible to reverse this trend, and to minimize if not resolve the prostitution problem by utilizing the Buddhist framework in order to facilitate change. Buddhism, they insist, can be envisioned as empowering this search to find an alternative spiritual merit-making option. Enabling women to seek full ordination as a bhikkhuni within the Buddhist monastic 
system, or even granting them more opportunities to pursue spiritual education via the mae chi role, would require a shift in political, social, and economic sectors of society. Defining the Terms

In order to understand the argument being set forth, it is essential to define the key roles (players) and to briefly introduce important Buddhist terminology and its use in Thailand. Since the Thai Buddhist tradition follows the orthodox Theravada tradition of India, which is said to be the oldest and most accurate teaching of the historical Buddha, Siddhartha, I will only use the Pali form of Buddhist terms.

I will begin by introducing the three central key players that need to be described in detail to understand their significance in this work. The first is the sex trade worker. I will use the word "prostitute" interchangeably with the word "sex trade worker" throughout this work because both terms refer to an individual who performs sexual acts for payment. Whether an individual works in a massage parlor, internet café, hair salon, or a brothel, if sexual acts are being performed, she will be considered a sex trade worker.

Perhaps one can argue that the term "prostitute," which may imply a negative judgment, is harsher than the term "sex trade worker." In this study, no such judgment will be made. However, it can be noted, in some cases that the Thai media has shifted to using "ladies of the night" as a way to describe female sex trade workers/prostitutes in order to legitimize the marketing of the trade to foreign tourists. Another significant thing to keep in mind is that only women sex trade workers and/or prostitutes are being referred to in this study, although the Thai sex trade industry does involve male workers as well, on a smaller scale. The important aspects regarding the role of Thai women, historically and contemporarily, will be discussed in Chapter Two, which focuses on 
some of the problems with women entering the sex trade. Chapter Three examines the economic, political, and social factors of the Thai sex trade industry in more detail. Human rights and HIV/AIDS, along with prostitution law in Thailand, will be discussed. The dynamics of Buddhism's connection with the sex trade industry in Thailand will be highlighted in Chapter Four, illustrating how the Thai concept of "merit-making" is linked to women.

The second key player, the Thai mae chi, is a Buddhist nun who adheres to between five and nine precepts (rules of conduct) and wears white robes. Mae chis live, study, meditate, eat, and work in either exclusively female nunneries throughout Thailand, or inside a wat (Buddhist temple) where there is separate housing for both mae chis and bhikkhus (male monastics). Mae chis are established and recognized by the Thai Buddhist Sangha, but lack the cohesive organizational structure which could grant them further privileges. The situation regarding the mae chi movement will be discussed in Chapter Five, which will examine their ambiguous status within Thai society as well as their goals for the future.

The third and last key player is the bhikkhuni. The bhikkhunis are Theravada Buddhism's, fully ordained "female monks" which, according to traditional theology, are not supposed to exist in Thailand, although they do in actuality. The term bhikkhuni is defined in Pali Buddhist terms as an ordained Buddhist nun, but because this thesis deals with the Thai equivalent of nun, the mae chi, I will differentiate between the two by referring to the bhikkhunis as "female monks." The bhikkhunis adhere to 311 precepts

\footnotetext{
${ }^{6}$ I prefer this definition because the leading proponent for the introduction of bhikkhunis in Thailand, Venerable Dhammananda (a bhikkhuni herself) uses this classification.
} 
and wear saffron robes. The Vinaya lineage that the Thai Theravada bhikkhuni adheres to is the Bhikkhuni Patimokkha of the Theravada tradition. ${ }^{7}$ The bhikkhunis have yet to be recognized and are fighting for equal access to Buddhist monasteries and similar privileges as bhikkhus. Since Thailand never officially contained a Bhikkhuni Sangha, these women are currently trying to establish a lineage. Chapter Six will highlight the historical and modern problems with the rise of the bhikkhuni movement.

Three additional Buddhist terms must be defined for the purpose of this thesis. The first is sangha. The term sangha is meant to describe the members of the Buddhist community. However, the members of the community can include as well as exclude the lay followers of Buddhism. In my discussions with a Sri Lankan monk, Upananda, ${ }^{8}$ during the time of the Buddha himself, the term sangha referred to the four pillars. The four pillars are said to include the bhikkhus, the monastic order of monks; the bhikkhunis, the monastic order of nuns; the upāsaka, the lay community of males; and the upāsikā, the lay community of females. The lay community is viewed as important to the monastic community because without the support of monetary donations and food offerings, the monastic order could not survive or continue to flourish.

In more recent times, especially in the Thai tradition, the concept of the sangha refers only to the monastic order, which in the Thai case consists only of bhikkhus. This conventional way of looking at the term sangha is linked to the observance of the Triple

\footnotetext{
${ }^{7}$ For additional information, see the work of Chatsumarn Kabilsingh, The Bhikkhuni Patimokkha of the Six Schools (Bangkok, Thailand: Thammasat University Press, 1991). Dr. Kabilsingh was a professor of Buddhist philosophy at Thammasat University in Bangkok, Thailand, before becoming a bhikkhuni.

${ }^{8}$ Upananda is a fellow FIU Religious Studies MA student who has been a practicing Theravada Buddhist monk of Sri Lanka since the age of 13.
} 
Gem of Buddhism: the Buddha, the Dhamma, and the Sangha. In this approach,

Buddhists are to seek refuge in all three Gems. First, one must seek refuge in the

historical Buddha for having discovered the path to enlightenment and for having taught

it to others. Second, one seeks refuge in the Dhamma as the source of his wisdom that is revered as the absolute teaching. Third, one seeks refuge in the Sangha as the monastic order by which the laity should follow as a model for right living in this world.

The concept of following the sangha as a model is interesting since Thailand is one of the few Theravada Buddhist countries that allow temporary ordination. ${ }^{9}$ Also, the relationship that exists between lay women and bhikkhus is said to be very delicate, as bhikkhus are supposed to limit their lone interactions with women and to be cautious with them for fear that the bhikkhus may be steered from their righteous monastic path. In "Attitudes toward the Feminine in Early Buddhism," Alan Sponberg quotes the Anguttara-Nikaya, which describes a conversation the Buddha had with the bhikkhus. Because the Buddha was once a young, married prince who was sexually experienced, he was quite aware of the human power of sexual attachment. It is written, monks, I see no other single form so enticing, so desirable, so intoxicating, so blinding, so distracting, such a hindrance to winning the unsurpassed peace from effort...as a woman's form. Monks, whosever clings to a woman's forminfatuated, greedy, fettered, enslaved - for many a long day shall grieve... ${ }^{10}$

\footnotetext{
${ }^{9}$ Alhough there are two different levels of ordination, one for the bhikkhu and the other for the novitiate, the distinction is rarely observed and understood from the Thai lay side of the equation because the line is rather blurred. This will be discussed in greater detail in Chapter Two regarding Buddhism's role in state affairs.

${ }^{10}$ As quoted in Alan Sponberg, "Attitudes toward Women and the Feminine in Early Buddhism," in Buddhism, Sexuality and Gender, ed. Jose Ignacio Cabezon, 3-36 (Albany, NY: State University of New York Press, 1992), p. 20.
} 
In Thailand today, bhikkhus remain aware of the female form as they closely monitor their interactions with the opposite sex. This ancient passage sheds light on the modern day situation, as does a similar remark made by scholar John Van Esterik when he stated, "women are doctrinally polluting to their effect on monks since any slight, even accidental, physical contact between a monk and a woman must be ritually expiated."11

The role that the sangha plays within the Buddhist community is further complicated by the idea of "merit," the final Buddhist term that needs to be identified. In the simplest of terms regarding lay Buddhists, merit is received when a lay follower donates food or money to the sangha. ${ }^{12}$ Merit is also accumulated through the laity serving and honoring the sangha. ${ }^{13}$ The act of giving and providing alms is known as dāna. Dāna is considered the first of three grounds for meritorious action in Theravada Buddhism. The "field-for-merit" is described in the following way by scholar Yoneo Ishii:

like a paddy field that yields rice for the sower of the seed, 'a field of merit' is the recipient of an offering that is believed to yield 'merit' for the offerer... a field for merit can be defined, at least in the Thai context, as a beneficiary of good deeds performed by people for the fulfillment of their desires for heavenly happiness. ${ }^{14}$

${ }^{11}$ John Van Esterik, "Women Meditation Teachers in Thailand," in Women of Southeast Asia: Monograph Series on Southeast Asia Occasional Paper No. 9, ed. Penny Van Esterik, $42-54$ (Detroit, MI: The Cellar Book Shop, 1982), p. 47.

${ }^{12}$ Although the concept of merit can be explained in more detailed terms, I will limit the discussion to its relevance to this study and how it is generated by lay women, since this is important to the understanding of how Buddhism relates to the sex trade. The Thai word for merit is bun, which will be used later in this manuscript.

${ }^{13}$ For additional reading, see Nathan Katz, Buddhist Images of Human Perfection (Delhi: Motilal Banarsidass Publishers, 1989).

${ }^{14}$ Yoneo Ishii, Sangha, State and Society: Thai Buddhism in History (Honolulu, HI: University of Hawaii Press, 1986), p. 13. 
As part of the sangha, monks are viewed in Thai culture as "fields-for-merit." This is why dāna is typically provided to the established sangha, as opposed to giving offerings to mae chis or other spiritually gifted non-ordained members of the Buddhist religious community.

In Thailand, dāna is the prescribed path of lay Buddhist women. Although the mae chi role is available to women, many do not choose it because of its low social status. The concept of "merit-making" in Thailand is taken very seriously, and oftentimes families will give up even their most precious possessions in order to generate it. As will be highlighted later, young woman often sacrifice themselves to prostitution in order to provide for their poverty-stricken families. This act is viewed as merit-making because the money that is generated towards the income of the home is an ultimate symbol of selfless sacrifice for a greater good. Additionally, some of the money will be taken to the temple as a donation, which is viewed as directly generating merit. 


\title{
CHAPTER TWO
}

\section{GENDER AND RELIGION IN THAILAND}

\author{
Women's Role in Society ${ }^{15}$
}

In modern Thai society, women are receiving and enjoying more opportunities and freedoms in the workplace, as well as in the universities. ${ }^{16}$ Their potential to serve as agents for the economic gain of their family units is increasing every day, as they hold important key positions in the government and business sectors of Thailand. The scholar William G. Skinner is noted for analyzing the results of a 1947 Bangkok census, which statistically described the occupational division of labor by sex. ${ }^{17}$ His analysis concluded that Thai women were overrepresented in the economically oriented occupations, such as small or large business owners and managers, jewelers, and hotel and restaurant employees. $^{18}$

${ }^{15}$ It is a difficult task to describe what a "typical" women's role in Thai society is since there is a large disparity between rural and urban sections of Thailand. Unless otherwise stated, I will speak from a modern, middle class, urban perspective.

${ }^{16}$ Thailand's women are known to enjoy particular advances in women's rights because of their open relationship with Western countries during both the pre-modern and modern ages. Thailand was never colonized by the West, but rather Thailand learned and grew from the cultural exchange.

${ }^{17}$ See William G. Skinner, Chinese Society in Thailand (Ithaca, NY: Cornell University Press, 1957). Skinner makes an even narrower distinction between Chinese and Thai dominated sectors of the economy, implying that women were being overrepresented in the Chinese sectors rather than the Thai ones.

${ }^{18}$ This was even apparent to me as a foreign visitor to Thailand as I compared the occupations between husband and wife of one of my middle class Thai family friends. Taken from Thomas Kirsch, "Buddhism, Sex Roles and the Thai Economy," in Women of Southeast Asia: Monograph Series on Southeast Asia Occasional Paper No. 9, ed. Penny Van Esterik, 16-41 (Detroit, MI: The Cellar Book Shop, 1982). 
As a first-time visitor to Thailand, I observed how a middle class family operates and just how a woman's role in the kingdom functions. Supapol "Ann" Boonian is a Buddhist, a wife, and a mother of two who holds an executive secretary's position at the Sheraton Hotel in Bangkok. Her husband, Suthep, was not the main wage earner for the home, as his work was not full time and was rather infrequent. Observing how Ann had to work all day, every weekday, and how her husband had the free time to show me around the city, ${ }^{19}$ suggested that women are not staying at home or working less than their spouses.

However, women in Thai culture still hold a burdensome position within the household structure which requires them to be involved directly with matters of the home by being both a dutiful wife and a mother, along with holding down a job. The scholar John Van Esterik states,

women are barred from being monks, but women can seek positions of high status in certain areas of Thai society. Thai women can be educated. They can teach, amass money and property, and become professionals in many fields. ${ }^{20}$

This suggests that women can be successful in many areas of Thai society, but cannot obtain a higher status within the dominant religious system. Women's acceptance into the economic and educational sectors of modern society seems tainted with reservations reflecting religious and cultural biases that must be overcome.

Another factor that affects the role of women is the view that they should focus on affairs of this life, otherwise known as this-worldly matters. The Thai cultural view

\footnotetext{
${ }^{19}$ One might expect that this would be the other way around.

${ }^{20}$ John Van Esterik, "Women Meditation Teachers in Thailand," in Women of Southeast Asia: Monograph Series on Southeast Asia Occasional Paper No. 9, ed. Penny Van Esterik, $42-54$ (Detroit, MI: The Cellar Book Shop, 1982).
} 
regarding Buddhism distinguishes between matters of this-world (here and now) and matters of the other-world (nibbāna). This is the case because Thai society glorifies the position of bhikkhu, and since this role is only available to men, women's roles are bound to concerns of this-world. The meritorious acts of Thai women providing bhikkhus with donations, while also serving the monastic community in other ways, are examples of this-worldliness. The condition of women's Buddhist service pushes them into a subservient position.

However, some Buddhist scholars argue for an entirely opposite interpretation of Buddhism, as they are against the view that it is other-worldly. One such claim is made by Harvey Aronson. He suggests that Buddhism should not be viewed as other-worldly because this is confusing and inaccurate. He refutes the claim that detachment (upekkhā) is the ultimate value of Buddhism when he states:

if detachment means the sublime attitude equanimity...this is not the most highly valued attitude in Theravada Buddhism. Buddha and his followers did not limit themselves to an attitude of neutrality with regard to beings, nor did they ever assert that this is the only or even best attitude to have...it would be more fitting to assert that the ideal act in Buddhism is governed by concern for other's happiness and welfare. ${ }^{21}$

According to Aronson, Buddhism is not merely a religion that aims at the achievement of enlightenment, but rather one concerned with matters of the secular world. To view Buddhism as other-worldly, in his opinion, suggests that an inadequate interpretation of the Buddha's teachings and of the scriptures has been made. "The

${ }^{21}$ Harvey B. Aronson, Love and Sympathy in Theravada Buddhism (Delhi: Motilal Banarsidass Publishers, 1989), p. 95. 
Buddhist teachings do not suggest that we give up intentional activity in general, rather that we give up fixated adhesion to things and ideas." 22

Another concern regarding the view of Buddhism as other-worldly is brought to light by Nathan Katz's review of Buddhism and politics in Sri Lanka. He suggests that:

the image of Buddhism as an other-worldly religion, unconcerned with and aloof from everyday problems of politics, economics, and society has been the lynchpin on the discourse of oppression. This image... has not been a mere intellectual misapprehension but has been a deliberate mainstay in the colonial administration of Sri Lanka, Burma and elsewhere. By separating the sangha from society, a power vacuum was created and immediately filled by the colonizer. Buddhist society, once it had been conceptually, economically, and militarily divorced from Buddhism, was made amendable to colonial manipulation under the guises of liberal secularism and so-called modernity. ${ }^{23}$

According to Katz, when seen against the backdrop of modernity and as a product of colonialism, the view of Buddhism as other-worldly is not truly at the heart of the historical teachings of early Buddhism. Perhaps a contemporary approach, SociallyEngaged Buddhism, ${ }^{24}$ which deals with Buddhists acting on social issues, is a response to the negative conditions brought forth by colonialism and modernity. Participants of the Socially-Engaged Buddhist movement are viewed as actualizing the traditional Buddhist ideals of wisdom and compassion in a way that leads them to act against injustice in their community. However, it does not seem that Thai Buddhists are heavily involved in this

${ }^{22}$ Harvey B. Aronson, Buddhist Practice on Western Ground (Boston, MA: Shambhala Publications, 2004), p. 154.

${ }^{23}$ Nathan Katz, "Buddhism and Politics in Sri Lanka and Other Theravada Nations Since 1945," in Movements and Issues in World Religions: A Sourcebook of Developments Since 1945, eds. Charles Wei-hsun Fu and Gerhard E. Spiegler, 157-175 (New York: Greenwood Press, 1987).

${ }^{24}$ See Fred Eppsteiner, ed., The Path of Compassion: Writings on Socially Engaged Buddhism (Berkeley, CA: Parallax Press, 1985); and Ken Jones, The New Social Face of Buddhism: A Call to Action (Boston, MA: Wisdom Publications, 2003). 
movement, at least from the monastic perspective, since the nature of the Thai sex trade industry is rarely debated amongst the Buddhist Council of Elders.

It seems that women in Thai culture today are still expected to be concerned with this-worldly matters, meaning family and money. In a case study by Penny Van Esterick about a young Thai village girl who had chosen to leave her village to become a mae chi for three years, it is written,

...her lack of interest in men and her disinterest in bearing children make her suspect. To other young villagers, her meditation exercises were evidence, not of piety, but of laziness, and they criticized her for not supporting her family economically. ${ }^{25}$

The common case in Thailand is for women to be involved in traditional roles like bearing children and taking care of the household. Thus, women should not seek other duties that will take them away from their household responsibilities. Whether these opportunities are to gain spiritual insight or to gain more economic resources for the family, they should not be a women's priority. This can also suggest that women should be less interested in pursuing the Buddhist monastic role, since the religion stresses the importance of other-worldliness, which is in direct conflict with the prescribed social role of women.

Generally, the position of ordination in the Buddhist religion in Thailand is thought to be reserved for monks because of their ability to renounce this-worldly matters. One can argue that a reason why the introduction of the bhikkhuni movement in Thailand has not strengthened in recent years is due to the fact that women are not culturally

\footnotetext{
${ }^{25}$ Taken from Penny Van Esterik, "Laywomen in Theravada Buddhism," in Women of Southeast Asia: Monograph Series on Southeast Asia Occasional Paper No. 9, ed. Penny Van Esterik, 55-78 (Detroit, MI: The Cellar Book Shop, 1982).
} 
viewed as renunciates. This further leads to the negative opinion regarding the mae chi position, as they are viewed as neither ordained nor lay Buddhist women (householders), which means they are not respected as typical upassika who are admired for their puññaproducing abilities.

Some part of the predominance of negative views regarding women in Thailand can be traced to the extensive Indian and Chinese cultural influences. The first known influence came into play during the Sukohthai period of Thai history (1234-1438). This period was marked by the introduction of various legal scriptures, one of which was Buddhist while the other two were of Indian Hindu background. The Manu Dharmasastra (a Hindu text) is noted by Thai Buddhist scholar Chatsumarn Kabilsingh as introducing social norms which "were repressive for women in greater or lesser degrees and formed the basis of Thai social norms and laws." ${ }^{26}$ According to the Hindu texts, women were viewed as possessions of men based on the relationship a woman had to a man: as daughter, wife, or mother. Women were to stay under the guidance and protection of the father, husband, and their son, and were traditionally not viewed as independent human beings.

In addition, during the reign of King Rama II (1809-1824), a trade relationship was developed between China and Thailand. Because many Thais intermarried with the immigrating Chinese, Chinese cultural ways were incorporated into Thai society. Five negative characteristics were designated to women based on the traditional Chinese belief that women are: (1) easily manipulated, (2) always unsatisfied, (3) jealous, (4) insulting,

${ }^{26}$ Chatsumarn Kabilsingh, Thai Women in Buddhism (Berkeley, CA: Parallax Press, 1991), p. 15. 
and (5) of lesser intelligence. ${ }^{27}$ Not only were women defined as inferior to men based on the premise of gender in Thai history, but later the dynamic of class would add another demeaning dimension to the prejudice.

In Thailand's history, women were viewed as being doubly exploited, first by means of the Thai societal class structure, and second through the gender bias within that structure. ${ }^{28}$ Kabilsingh argues that although women have received privileges in the areas of education, the marketplace, and politics, negative gender biases still exist. She suggests that women have often accepted their status without complaint because "exploitation, whether physical, legal or cultural, has been justified on the basis of kamma ${ }^{29}$ and has therefore been accepted as the expression of religious principle. ${ }^{, 30} \mathrm{On}$ one social level, some women are receiving university education, while others are barely completing their primary schooling. Having traveled throughout Thailand after the 2004 tsunami disaster, I observed how the upper classes enjoyed the privilege to attend expensive international universities, yet how many poor families could not afford to send both their sons and daughters to primary school. ${ }^{31}$

${ }^{27}$ Ibid., p. 19.

${ }^{28}$ Cited by Kabilsingh, from Kularb Saipradit and Jit Bhumisak, History of Thai Women (Bangkok, Thailand: Somchai Press, 1976).

${ }^{29}$ Kamma is the Pali word which means one's intentional actions have subsequent consequences. Those consequences can result in either a more or less favorable rebirth.

${ }^{30}$ Kabilsingh, p. 16.

${ }^{31}$ In the case of education for the poor young rural girls, they either hoped to earn scholarships from various NGOs offering money for school or had to sacrifice their right to education so that their brothers would achieve success. This also describes the perfect condition for young girls to be sold or coerced into working for the sex trade. 
Within the marketplace, ${ }^{32}$ some women are enjoying the freedom to serve as members of parliament or to hold upper-tier management positions, while others are being employed as skilled laborers who are paid low wages in either agricultural or industrial industries. Thai women are granted a great deal of control of the management of the family's finances, which is a this-worldly concern. However, this role does not necessarily lead to economic control, for as Kabilsingh states, "women have no real economic power, but do have the responsibility to make ends meet."33 Again, we are witnessing how even though Thai women are being utilized in the economic realm to both contribute and manage household finances, and they are not allowed to do it without their husbands being involved. This is not to say that married women should not accept some support from their spouses, but rather suggests that women are always under the direct supervision of their husbands.

With regard to the political sector, Thai women have held the right to vote even before some European nations granted women voting rights. Kabilsingh suggests that although greater numbers of women are participating in political affairs, they are often limited by the lack of financial support which is necessary to lead successful campaigns. ${ }^{34}$ The Thai social perception of women as leading political figures is still somewhat of a radical ideal, although there are many female members of parliament.

\footnotetext{
${ }^{32}$ The consumer environment which facilitates the exchange of goods, services, and products.

${ }^{33}$ Ibid., p. 19.

${ }^{34}$ She has noted that in the future decades it is unclear what role Thai women will play in direct political life as Thai social norms are changing everyday.
} 
Thailand's view of women can be interpreted both positively and negatively, as most would agree there is still a gender imbalance.

Buddhism and the State

Buddhism's relationship with the government is intricate, as control of the Thai Buddhist sangha has remained under the jurisdiction of the state since the $19^{\text {th }}$ century. The king as monarch and head of the Thai nation is the "sole" defender of Buddhism, continually supporting and advocating for its prosperity. ${ }^{35}$ The king has a responsibility to uphold the Buddhist religion, although the Thai Buddhist sangha has the same responsibility among others. The sangha is actively involved in upholding the Buddhist religion in Thailand, as Buddhism is viewed as playing an integral and pervasive role in Thai social and ethical values, since to be Thai is to be considered Buddhist. Even though politics is viewed as a this-worldly concern, Buddhism as an other-worldly religion, as defined by Van Esterik, is still represented on all levels of the political sphere. As both Yoneo Ishii and Van Esterik point out, there is important political significance in the state's direct involvement in protecting the sangha and maintaining its purity. This is so because the basic structure of the traditional polity and of the Buddhist "state" religion is equally bound by the importance of Budhist "law," otherwise known as dhamma, since it is viewed as the legitimating factor for the monarchy. ${ }^{36}$

The legitimacy of rule in Thailand is viewed as being derived from the dhamma. Ishii notes,

${ }^{35}$ It is considered an ancient Thai custom for the king to profess Buddhism as his given religion.

${ }^{36}$ The quote listed below explains this triangular relationship in more detail. 
the 'Buddhist-state,' defined as a state structure such that the king supports the sangha, the sangha transmits the dhamma and the dhamma legitimates the monarchy...legitimated by the dhamma the king secures the following of the people. The dhamma, on the other hand, must be transmitted by a pure sangha: the dhamma's survival is guaranteed by the purity of the Sangha. ${ }^{37}$

The uninterrupted circle first involves the king as the defender of Buddhism and the sangha. The sangha then is the transmitter of the dhamma through teaching and direct contact with the laity. The dhamma is then viewed as the legitimating principle which honors the king, but it must stay true to form and pure in its transmission. It can be stated that the Thai political structure relies on the monks to legitimize its authority, although the sangha is supposed to remain uninvolved in political initiatives except in times of crisis. $^{38}$

In Thailand, the Buddhist sangha, as well as other religious traditions throughout the kingdom, are governed through the Religious Affairs Department. The Religious Affairs Department operates directly under the Ministry of Education, which finances religious education and funds two state-run universities for monks and also finances the construction and restoration of Buddhist monasteries, in addition to other religious places of worship (mosques and churches). Because the Thai government is set up this way, it both defines and prosecutes religious offenses. Such offenses would be the impersonation of a monk or committing acts which are considered insulting to the religion. This is how

${ }^{37}$ Ibid., p. 47.

${ }^{38}$ One such crisis which deserves to be mentioned is the ethnic/religious violence coming out of the Southern provinces of Thailand currently. The state and Buddhist sangha is getting directly involved in professing Buddhism as the "state religion" and denouncing all acts of religious violence proclaimed against the Buddhist religion and its adherents. 
the Thai government is able to uphold a state ban prohibiting the ordination of women. ${ }^{39}$ From time to time, there have been movements of members of the Thai Parliament who have challenged the ban against allowing monks to ordain women, although none have proven successful as of yet. ${ }^{40}$

This close relationship between the state and the sangha is a double-edged sword. The royal government's patronage of the Buddhist sangha guarantees protection and many privileges for Buddhism, but it also grants the government control of the Buddhist order. For example, when a local Buddhist matter is not being handled in the "proper" way, in line with the definition of traditional Buddhist dhamma, the government curtails the sangha's involvement. A first-hand example of this was observed in July 2005 at temple Wat Songdhammakalyani in Nakhon Pathom Province.

While visiting Bhikkhuni Dhammananda at her temple, Wat Songdhammakalyani, I witnessed how the state supersedes the sangha for what it sees as protecting the Buddhist tradition. Venerable Dhammananda is currently the leader of the bhikkhuni movement in Thailand which is as yet unsuccessful, although bhikkhuni ordination had been previously introduced, to no avail, in two other periods during the $20^{\text {th }}$ century. ${ }^{41}$ Venerable Dhammananda and a Buddhist couple she brought along visited a Buddhist wat located across the busy freeway from her own. The couple supports the bhikkhuni

${ }^{39}$ See the Thai Penal Code Sections 206 and 208. Taken from Mahidol University's webpage on religions in Thailand: http://www.mahidol.ac.th/thailand/religions/relogions.html (accessed November 3, 2007).

${ }^{40}$ Chatsumarn Kabilsingh, Towards Ordination (Nakhonpathom, Thailand: Wat Songdhammakalyani, 2000), p. 21.

${ }^{41}$ The three waves of the Bhikkhuni Sangha in Thailand will be discussed in Chapter Five. 
movement and is noted as offering dāna to the bhikkhuni temple and its members in hoping to advance their future spiritual rebirths by acquiring merit. Dhammananda's intention was to get the abbot's signature on a form which was crucial to the advancement of the bhikkhuni cause, which witnessed the abbot's direct involvement and participation in a series of dhamma talks (Buddhist sermons/lectures) several of his monks had given to the women at Wat Songdhammakalyani. Earlier, the abbot had been a proponent for the introduction of bhikkhunis in Thailand and had agreed to assist Dhammananda in her quest for legitimation. However, after the state found out about his communications and affiliation with Dhammananda, the abbot was cornered. The state had threatened to remove him from power and thus successfully intimidated him from continuing any further contact or assistance to her and the bhikkhuni movement.

It was quite noticeable that Dhammananda and the Buddhist couple were not welcome at the wat that day. The Buddhist layman who escorted us to the temple was the one who attempted to locate the abbot for his comment. The abbot not only refused to see Dhammananda, but also requested that she, the couple, and myself, leave the premises. It was then by sheer luck that Dhammananda came across the junior monk who actually gave the dhamma talk to her congregation. He graciously signed the form, although fully aware of the fact it was seen as an act that could jeopardize his status as a bhikkhu. Upon receiving the signature, everyone left briskly, as the handful of monks who were in the vicinity were happy to see us go.

Dhammananda later explained to me the entire ordeal, although it was easy to understand the sense of tension in the air. She claimed that this was not the first incident nor would it be the last. She was upset on two different levels. The first was on a larger, 
theoretical scale having to do with Buddhism's role in the denial of this-worldly matters.

She felt as though the abbot of the temple should be above all concepts of title and self, since Buddhism denies these "earthly" designations, as in Buddhism the concept of selfhood is seen as the Great Illusion. One of the main ideas taught by the Shakyamuni Buddha was the overcoming of the condition of suffering $(d u k k h a)$. What then should the loss of power really mean to this mature, realized Buddhist monk?

On the grassroots level, Dhammananda was concerned with having to locate another wat and community of monks who would agree to facilitate her and the bhikkhuni movement by providing dhamma education. Bhikkhus must give dhamma talks to the bhikkhuni organizations on a monthly basis in order for the bhikkhunis to fulfill their duties based on the Patimokkha. Without this interaction, the bhikkhuni movement could not possibly be legitimated within the Theravada Buddhist tradition.

Since the state has an obligation to keep the sangha in check, the Buddhist religious institution in Thailand must stay quiet about political concerns. One of those concerns is Thailand's infamous global sex trade industry, which profits from the exploitation of women. ${ }^{42}$ Thai scholar and ex-monk Tavivat Puntarigvivat has seen firsthand how the poor of rural northern Thailand are pushed into prostitution. Young rural children are often sold into prostitution in order to provide for the rest of the family. ${ }^{43}$

\footnotetext{
${ }^{42}$ It can be noted that some women have chosen the profession without any outside influence, although most of the time prostitution affects the poor, young rural female populations of northern Thailand. The Thai sex trade industry does affect the male youth as well.

${ }^{43}$ For more information, see Lucinda Joy Peach's work, "Buddhism and Human Rights in the Thai Sex Trade," in Religious Fundamentalisms and the Human Rights of Women, ed. Courtney W. Howland, 215-226 (New York: St. Martin's Press, 1999).
} 
The deal may include a contract which states that once a debt is paid by the young girl through sex trade work, she can be returned to her village. This system is known as "debt bondage" and is typically quite difficult to pay off. Based on Puntarigvivat's experience as a Thai Buddhist monk in northern Thailand, he writes,

those who could hardly afford to feed their own families fed [me] daily-a custom of religious respect...[I] began to witness a new and very different custom of respect, a consumerism that led some to sell a daughter into prostitution-not to buy food for the family or a new water buffalo, but to buy a prized motorbike. ${ }^{44}$

Since Buddhism is kept in close association with state affairs because of the state-sangha relationship defined by the Thai Constitution, the government in part has kept the bhikkhus quiet concerning matters they feel strengthen Thailand economically.

On a final note, there is even a further association between Buddhism and the state since both are traditionally viewed as exclusively male pursuits. ${ }^{45}$ Although women are beginning to become more directly involved in Thai politics, they are still limited in their representation at higher level positions. As addressed earlier, women are given more freedom to pursue economic activities in other sectors of the Thai marketplace. This fact is problematic in two ways. First, it suggests that women are not suited for the position of government official or an ordained monastic, implying a cultural bias. Second, it indirectly allows for women to be pressured into taking illicit and dangerous jobs in other areas, such as factory work and prostitution. Although women's lack of education plays a role in both their exclusions and their culturally accepted role in the economy, it is not the only factor to be considered. Until women's rights are given more precedence in Thailand,

\footnotetext{
${ }^{44}$ Cited in John C. Raines, The Justice Men Owe Women: Positive Resources from World Religions (Minneapolis, MN: Fortress Press, 2001), p. 63.

${ }^{45}$ Van Esterik, p. 44.
} 
the way in which women are driven to make occupational choices can be hazardous to their mental, physical, and spiritual health. The history of the sex trade, its economic boom in Thailand, the HIV/AIDS crisis in Thailand, and the contemporary perspective on the Thai sex trade industry will be covered at length in the following chapter, which will serve as a bridge to Buddhism's relationship with the sex trade. 


\section{CHAPTER THREE}

\section{THE DYNAMICS OF THE SEX TRADE IN THAILAND}

It is important to note that this chapter will not include a discussion of religion, because it serves as a link to the following chapter on Buddhism's connection to the sex trade industry in Thailand. Before being able to analyze the role Buddhism plays in the sex trade, one must be aware of the dynamics regarding the practice in Thailand today, as well as throughout its history. The focus of this chapter will be to describe the Thai sex trade industry by evaluating its influence on both the economic and public health sectors. This overview will also comment on how prostitution law has contributed to the situation in recent times.

\section{Historical Reflections}

Thailand's relationship with prostitution is well known throughout the Western world today because it is the basis of a highly marketed form of tourism. However, Thailand's sex trade industry does not only service foreigners; the majority of clients are Thais themselves. This is not a modern phenomenon, as prostitutes served both local and foreign customers as early as the $14^{\text {th }}$ century. As scholars Wathinee Boonchalaksi and Philip Guest suggest, there is no clear evidence as to when prostitution in Thailand became widespread, although they trace it back to the Thai Ayudhya period (13501767) ${ }^{46}$ Historically, there was a close association between migrant communities, prostitution, and economic development. This extensive affiliation with prostitution allowed migrant communities to establish networks within the Thai culture that were both

\footnotetext{
${ }^{46}$ See Wathinee Boonchalaksi and Philip Guest, "Prostitution in Thailand," in The Sex Sector: The Economic and Social Bases of Prostitution in Southeast Asia, ed. Lin Leam Lim, 130-169 (Geneva: International Labour Office, 1998).
} 
business-oriented and socially based. Due to their social interactions, many outsiders married Thai women and assimilated into Thai culture.

Not much is written about prostitution during the Ayudhya period, except that the trade was legal and taxed by the government. Later, during the reign of King Rama I (1782-1809), there was a documented increase in the migration of the Chinese into Thailand. This played a major role in the continual growth of prostitution. As the male Chinese population grew, prostitution thrived because there was an increase in the demand for these services since it was prevalent and accepted in Chinese society. ${ }^{47}$ Areas where prostitutes lived and worked were known as "prostitute houses" and were generally located in and occupied by the Chinese community. One such location was central to the Chinese district of Bangkok known as Sampeng. Sampeng was well known for prostitution up to King Rama IV's reign (1852-1868).

Foreign cultures, including Europeans who came to Thailand, gave the sex trade a reason to expand because the influx of traders contributed to its economic viability. During King Rama V's reign (1868-1910), the tax that was placed on prostitutes and brothels in various provinces known as the "road tax," was well documented. This "road tax" was applied to foreign visitors and those individuals passing through Thailand who engaged in prostitution. The tax was not applied to the sex workers, but rather to the clients who used their services. ${ }^{48}$ The sex trade had become a well-established business

\footnotetext{
${ }^{47}$ Most of the prostitutes during this time were actually Chinese. However, the Thai ones would adopt Chinese names in order to be more popular with the foreign Chinese immigrants and travelers.

${ }^{48}$ Although prostitution was directly taxed by the king, it did not involve any kind of regulation.
} 
and one that was economically beneficial to the Thai government because it generated income from its own people and outsiders alike.

The most common form of prostitution during this time involved "stationed women." These women were either sold into a debt bondage system or were literally considered slaves who could be sold outright by their owners. ${ }^{49}$ The debt bondage system dealt with women being sold into prostitution in exchange for money. The women were held in the practice until their debt was paid off through sexual service. These debts were typically from people who sold the women into prostitution, such as husbands or family members. The Thai brothel, which is highly visible in contemporary Thailand, began during this period as a place where prostitutes worked and lived under the supervision of a manager. The managers were mainly there to collect fees and to ensure that the women were observing proper manners when dealing with their clients. As Boonchalaksi and Guest have noted, "reports indicate that the houses were very well managed; stealing was forbidden and clients who might forget their belongings had them returned." ${ }^{, 50}$ Brothels were not the only way prostitution was contained and practiced. Another form of prostitution was debt bondage women who performed sexual services on boats that were anchored in the city's harbors.

Things began to change slightly when King Rama V abolished slavery in 1905. For lack of other opportunities, many slaves voluntarily became prostitutes. This increased the number of sex trade workers dramatically, prompting the Contagious

\footnotetext{
${ }^{49}$ Leslie Ann Jeffrey, Sex and Borders: Gender, National Identity and Prostitution Policy in Thailand (Vancouver: UBC Press, 2002), p. 5.

${ }^{50}$ Boonchalaksi and Guest, p. 130.
} 
Disease Prevention Act to be passed just three years later. In summary, the avenue of prostitution was historically linked to the large scale Chinese migration and to some extent, the institutionalization of slavery. Due to the Chinese influence, Confucian values were heavily entrenched in Thai society by this time period, justifying the practice of prostitution and therefore allowing for the profitability of the sex trade practice to go unquestioned. Through this process, the monogamous codes for sexual conduct among married individuals became irrelevant to those involved. The modern century proved to be even more accommodating to prostitution and thus has had an enormous economic impact on Thailand.

\section{The Thai Economic Boom}

The period since the 1960s has ironically proved to be the period of most dramatic growth for prostitution, despite the fact that the government wanted to decrease the size of the sex trade industry. ${ }^{51}$ The problem from a political standpoint is that through the indirect jurisdiction and patronage of the government, sex tourism had increased significantly. The reason this occurred is multi-dimensional. First, due to modernization and changes in the cultivation of agriculture, the position of women in rural society has changed, since they were no longer needed to work the land. As Boonchalaksi and Guest note, "increasing productivity in agriculture in Thailand has been associated with decreasing opportunities for agricultural wage employment for women and increasing opportunities for men." 52 Women had also played a major role in the economic

\footnotetext{
${ }^{51}$ This period of growth correlates with Thailand's economic boom, which was also felt by other Asian countries during the same time period.

${ }^{52}$ Boonchalaksi and Guest, p. 134.
} 
development of their villages and had been key players in village polity until the Industrial Revolution reached Thailand, allowing new factory jobs to be created for men at the same time that women became surplus agricultural workers. Second, a change in inheritance rules allowed property to be split evenly between daughters and sons, although previously, daughters were given the entire inheritance. Since rural northern Thailand had been matrilineal, with these new changes in place, women were forced to migrate to bigger cities in order to find employment. However, they were still expected to support their parents, siblings, and children.

Because of the low education level of these rural women from northern Thailand, who were still substantially obligated to provide for their families, a relatively tolerant attitude towards prostitution arose. During the Vietnam War in the 1960s and early 1970s, American military personnel stationed in Vietnam or serving at other area military bases, were sent to Thailand for $R \& R$ (rest and recuperation) leave or what also came to be known as I\&I (intoxication and intercourse) ${ }^{53}$ With the development of the Tourist Organization of Thailand (TOT) in 1959, hotel operations, as well as entertainment places such as massage parlors, night-clubs, and bars, were regulated and operations legitimized. According to Jeffrey,

following recommendations from the World Bank that touted tourism as the cureall for Third World Development, the government supported increased investment in tourism infrastructure through the establishment of the Tourism Authority of Thailand. $^{54}$

${ }^{53}$ Rita Nakashima Brock and Susan Brooks Thistlewaite, Casting Stones: Prostitution and Liberation in Asia and the United States (Minneapolis, MN: Fortress Press, 1996) p. 58.

${ }^{54}$ Jeffrey, p. 77. 
Shortly after this, the negotiation for the first R\&R treaty was set in motion. It was signed

in 1967 between the Thai government and the US Military. Troung notes,

the lucrativeness of $R \& R$ activities was particularly significant given the large number of US soldiers stationed in Indochina. In 1967 it was estimated that the spending of US military personnel on R\&R leave in Thailand was from $\$ 5$ million US to around $\$ 20$ million US or as much as one-fourth of the total value of rice exports for that year. ${ }^{55}$

Through the encouragement of foreign investment and the promotion of tourism, Thailand's economy expanded at one of the fastest rates in the world from the mid-1980s to the mid-1990s. Tourism became the cornerstone of Thailand's economy during this period. According to Boonchalaksi and Guest, role expectations and other social and cultural factors related to prostitution operate within an economic structure that influences the supply of women willing to work in the sex industry, and also affects the demand for commercial sexual services." 56

Following suit, during the Vietnam War Period, Pattaya, a beach getaway in Central Thailand, developed a very visible sex industry which infiltrated hotels, restaurants, shops, bars, and nightclubs. This network is still in existence today and includes local internet cafes as well.

During the summer of 2005, I observed just how intimate a locale the internet café currently is in Pattaya, Thailand. Women in the internet cafes use chatting and web cameras to flirt and talk to their foreign clientele. While observing several loud women with their computer screens within clear sight, I saw that men chatting with them online in a different location were naked and touching themselves as they communicated via an

\footnotetext{
${ }^{55}$ Ibid.

${ }^{56}$ Boonchalaksi and Guest, p. 133.
} 
instant messenger chatting service with web cameras. The Thai women observed were fully clothed in sexy dresses as they spoke through headset microphones and broadcasted themselves through internet web cameras. The men chatted online with their Thai "lady friends" using their internet connections, web cameras, and headsets. ${ }^{57}$ This observation turned out to be not a rare occasion, but rather a quite normal and common situation in other cafes on different days. A traveler to Thailand using an internet café to keep in touch with family and friends may be shocked at just how open and accepted these services really are.

Pattaya has grown to include resort after resort along a string of once-beautiful bays, which is now a string of beaches riddled with waste. Phongpaichit, a Thai economist, states, "the sea-front was swamped in concrete. The sea was filled up with sewage. The ambience was buried under sleaze." ${ }^{, 58}$ The Thai economic miracle has not only affected women working in the sex trade industry, but has also had a striking affect on valuable parts of the Thai natural environment.

\section{Human Rights and HIV/AIDS}

The global community has become more aware of its international partners and their cultural behaviors. For better or worse, action is being taken in order to achieve an international standard on the basis of human rights. One indication of how a country

\footnotetext{
${ }^{57}$ It is not known whether the women had previously met these men or whether they were somehow solicited online and even if they were being paid for their conversations and time spent.

${ }^{58}$ Pasuk Phongpaichit and Chris Baker, Thailand's Boom and Bust (Chiang Mai, Thailand: Silkworm Books, 1998) p. 288.
} 
views and understands the role of international human rights is through an examination of the role of women and how they are treated in that particular society.

In Thailand, as previously mentioned, women have been directly affected by discrimination in many ways and in various spheres of Thai society. An aspect of discrimination in the sex trade industry is that, although some women freely make a choice to enter prostitution, many are coerced into doing so by outside forces. In such cases, prostitution is considered a human rights violation because it is viewed as an affront to womanhood that cannot be considered dignified labor. It can also be viewed as a human rights violation because of the way women are coerced into prostitution. Some groups advocate that prostitution and trafficking of women are forms of severe discrimination considered to violate women's human rights. Other groups rally behind the World Charter for Prostitutes' Rights, which aims at decriminalizing aspects of adult prostitution on the grounds that prostitutes are exercising free will. However, even these groups recognize that there is a difference between economically pressured women who are deceived into working for the sex trade and those who work as sexually liberated persons.

The local Thai populace until the 1990s did not develop an awareness concerning the extent of HIV/AIDS. Until this time, the Thai government refused to acknowledge the rapid rate of HIV transmission in the country. The illness was not viewed as a significant problem because the majority of the Thai population was in denial about it. The late 1990s marked an alarming increase in the rate of HIV infection in Thailand, which at one point was the highest in the world and eventually came to be thought of as a national crisis. 
Yet, as late as August 2005, an upcoming HIV/AIDS conference to be held in Thailand later that month was very poorly received by ordinary Thais. Talk amongst Thais I met was very negative regarding the conference. People were quite confused; they questioned why the conference was being held in Thailand in the first place. It was as if the mainstream of society was in complete disbelief that they had a problem with the global disease. There were visible protests against the conference on street corners and local news coverage highlighted the negative publicity. An Australian traveler I met who was sent to Thailand by his NGO and who was going to attend the conference in a few weeks, after he did some touring, was surprised at the negative publicity surrounding the event. He was unsure what to expect and was a bit alarmed and puzzled by all of the controversy. This occurred not only many years after the dramatic rise in HIV/AIDS infection in the country, but after a concerted government program to address the crisis. Since a dramatic rise in cases began, many studies were conducted in Thailand by mostly foreign services, although many local NGOs were also involved. ${ }^{59}$

One way to view Thailand's history of HIV infection is through an explanation of five waves. This analysis is made by the Thai researcher Thomas Steinfatt. ${ }^{60} \mathrm{He}$ points out that the first wave of the epidemic occurred in 1988 with a rapid spread of the disease by injection-drug users. The second wave included mostly female sex workers and those especially associated with brothels, whose rate of infection rose from $3.5 \%$ in 1989 to $33 \%$ by 1994 . In another study by Theetranont, it was noted that there was a "strong

\footnotetext{
${ }^{59}$ The extent of the studies concerning the spread of HIV/AIDS infection in Thailand defined the problem both quantitatively and qualitatively.

${ }^{60}$ See Thomas J. Steinfatt, Working at the Bar: Sex Work and Health Communication in Thailand (Westport, CT: Ablex Publishing, 2002).
} 
association among healthy young men in northern Thailand between HIV infection, visits to sex workers, and inconsistent condom use. ${ }^{, 61}$ The third wave spans the same time frame but includes male customers of the female sex workers. Their rate of infection rose from 0 to $8.6 \%$ during the years $1989-1994$. The fourth wave included the wives of the regular patrons of the sex workers whose rates grew from 0 to $2.3 \%$ from $1989-1995$ and rose again to $3 \%$ in 1996 . The fifth wave, referred to as vertical transmission, occurs when a child is born to a mother infected with HIV/AIDS. In a 1999 UN report, it was noted: "one of every four children in Thailand born to an HIV-infected mother is HIVpositive, and two of every three of these children develop AIDS by their second birthday, resulting in 80,000 deaths among children under the age of 10 by the year $2002 ., 62$

Although the rates of HIV/AIDS infection have increased largely due to commercial sex, it cannot necessarily be blamed entirely for the spread of AIDS in Thailand. ${ }^{63}$ This is true because of non-commercial sex relations between partners who are neither married to sex workers nor work in the sex trade themselves having a history of prior sexual activity with partners who could have transmitted the virus to them. There is a common belief that non-commercial sex is considered less risky, so many feel that this lower risk warrants having sex without any protection. However, as previously mentioned, this is a misguided and even dangerous notion, since it is not always the case that protection is not needed.

\footnotetext{
${ }^{61}$ Steinfatt, p. 187.

${ }^{62}$ Ibid.
}

${ }^{63}$ Chanpen Saengtienchai, "Prostitutes are Better than Lovers," in Genders and Sexualities in Modern Thailand, eds. Peter A. Jackson and Nerida M. Cook, 78-92 (Chiang Mai, Thailand: Silkworm Books, 1999), p. 90. 
Although Thailand had a weak start in dealing with the HIV/AIDS crisis, it has effectively brought down the rates of infection and has made great strides in HIV/AIDS education and health care. In an article dated August 17, 2006 from the on-line Complete HIV/AIDS resource, The Body, it is stated,

...if Thailand had not launched wide scale HIV/AIDS prevention programs, the country would have recorded 7.7 million HIV cases and 850,000 AIDS cases in 2005-14 times the number of cases the country currently records... Thailand's past success with prevention is the most important reason the country can afford universal access to (AIDS treatment) today. ${ }^{64}$

Prevention programs that began in the late 1990s included the $100 \%$ condom program which enforced mandatory condom use in brothels, as condoms were distributed free of charge to commercial sex establishments. ${ }^{65}$ A massive public information campaign on AIDS aired anti-AIDS messages every hour on the country's 488 radio stations and six television networks, while every school was required to teach AIDS education classes, and as the HIV/AIDS education budget was increased to $\$ 44$ million in 1993. ${ }^{66}$ Thailand's progressive and well funded prevention programs were quite effective in lowering the rates of disease, making it a model for other nations like India and China which were also dealing with an increase in cases.

However, with the Asian financial crisis of the late 1990s, by the year 2000, funding for HIV/AIDS prevention in Thailand was reduced by one quarter. In another

\footnotetext{
${ }^{64}$ Henry J. Kaiser Foundation contributors, "Thailand's HIV/AIDS Treatment, Prevention Programs Should Serve as Model for Other Countries, Report Says." www.thebody.com/content/news/art7905.html (accessed on 2/5/08).

${ }^{65}$ These national programs were directed at decreasing the rate of infection from the commercial sex sector.

${ }^{66}$ Annabel Kanabus and Jenni Fredrikson, "The History of HIV and AIDS in Thailand." www.avert.org/aidsthai.htm (accessed 2/5/08).
} 
year, the domestic funding for these programs decreased by half and was even cut by two-thirds in 2006. This dramatic decrease led to complacency among the government and public, posing a real threat to current HIV/AIDS prevention in Thailand. It is noted,

there have not been any mass public prevention campaigns carried out in Thailand for over a decade. This has led to a decline in awareness and possibly an increase in unsafe sexual behavior, especially among young people who are often not old enough to remember campaigns that were carried out during the $1990 \mathrm{~s} .{ }^{67}$

Since 70 percent of STI cases in Thailand occur in the age group of 18-24 year olds, young people are clearly vulnerable to HIV infection.

Other areas of concern in Thailand regarding future HIV/AIDS prevention and treatment deal with migrant workers and ethnic minorities and their access to the country's public health system, the strain on health workers resulting from the influx of HIV-positive patients, and the need for second-line drugs for patients who are resistant to first-line treatment. In addition, there needs to be an increase in prevention efforts among high risk groups such as men who have sex with men and IV injection drug users. Regardless of the progress Thailand has made with HIV/AIDS prevention and treatment, the disease will continue to be an area of concern in the current century so long as Thailand's sex trade industry and sexual practices remain unchanged and unquestioned.

\section{The Modern Perspective and Prostitution Law}

We have seen that the sex trade has a long, complicated historical record in Thailand and how the spread of a contemporary deadly disease has impacted the problem. We have also observed how the tourist industry has played a role in developing sex tours and propagating the sex trade throughout Thailand. Now, we will probe the current

${ }^{67}$ Ibid. 
dynamics of the sex trade with particular regard to numbers of sex workers and the establishments in which they work, while also discussing what the law says regarding the practice.

Some people may not be aware that, although commercial sex is a major component of tourism normally involving bars, hotels, brothels, and entertainment quarters, it is also associated with non-tourist establishments like massage parlors, tea houses, golf clubs, members' clubs, and restaurants. Surprisingly, restaurants have the highest numbers of sex workers while bars/nightclubs come in second ${ }^{68}$ However, prostitution in Thailand, despite being economically successful, highly visible, and easily available, is an illegal practice. Local politics in Thailand have a great deal to do with the "why" and "how" regarding the retention, exploitation, and continual use of prostitution as an economic resource in a predominantly Buddhist (in theory, non-prostitution promoting) culture. ${ }^{69}$

The current number of sex trade workers in Thailand can only be estimated, as some reports exaggerate the numbers in order to make a case against the practice, while others do not include the full number of women because many fail to register with the Public Health Ministry. Although the work of the Public Health Ministry (PHM) is usually known to be quite thorough, a report presented at the Ninth International Conference on Aids in 1993 by Sittitrai refuted the PMH's numbers. Sittitrai's findings are almost double the number of sex workers that the PMH reported for 1992 . The point-

${ }^{68}$ Boonchalaksi and Guest, pp. 138-139.

${ }^{69}$ For further information see Pasuk Phongpaichit, Sungsidh Piriyarangsan, and Nualnoi Treerat, Guns, Girls, Gambling, Ganja: Thailand's Illegal Economy and Public Policy (Chiang Mai, Thailand: Silkworm Books, 1998). 
in-time estimate taken from Steinfatt's research for 1992 was 120,000-150,000 sex trade workers in establishments throughout Thailand. This number included workers in all venues, such as those mentioned above.

Regarding prostitution law, the practice first became illegal in Thailand in 1928, when a mandate defined penalties for women living off the income of prostitution, including high penalties for those girls under the ages of eighteen and fifteen and even higher for those under fifteen. ${ }^{70}$ In 1960 , only seven years before the economic boom, which profited from the promotion of prostitution, the Anti-Prostitution Law made both prostitutes and procurers liable to a fine or jail term, although it imposed no penalties on customers. ${ }^{71}$ Amendments in 1996 reduced the penalties on the prostitutes themselves, introducing for the first time a penalty for customers who engage in sex with girls below the age of eighteen as well as penalties for the under-aged girls' parents if they act as an accessory. However, as Steinfatt points out, "not a single case of a customer charged with sex with an under-aged worker had gone to the courts in Thailand." 72 Since prostitution is lucrative, highly visible, and still growing, establishment owners regularly relinquish protection money to the Thai police to keep their businesses out of legal trouble. Depending on the case and circumstance of the sex trade worker, individuals may be doubly exploited by their employers as well as by the police.

In 1996, a study conducted by the Counter Corruption Commission in Thailand outlined four major reasons for the lack of police enforcement of the prostitution laws.

\footnotetext{
${ }^{70}$ Lim, p. 210.

${ }^{71}$ Ibid.

${ }^{72}$ Steinfatt, p. 17
} 
First, the police do not carry out their duties because they believe that sex trade work is not as serious as other crimes. Second, superior police officers do not pay enough attention to the sex trade industry, since their appearance at known establishments is only requested once in a while. Third, because the owners/operators of sex service establishments are usually local, influential people, including senior police officials, the local police fear that overstepping boundaries can affect their careers and livelihoods. Finally, since the anti-prostitution laws only pertain to establishments listed as providing sexual services, like brothels and night clubs, the bulk of the current Thai sex sector which includes such places as bars, tea houses, massage parlors, and hair salons is immune to restriction and registration, and is able to operate legally without concern. Being that the latter are not listed with commercial sex dealings as their primary function but rather as providing some other kind of service as a front to the sexual services made available there, they are not subject to the same laws. Because of this covertness in the sex tourism sector, in which enterprises that are not normally associated with sexual service are now being incorporated into the commercial sex sector, individuals, associations, and establishments which hold power can continue their lucrative business ventures without any supervision or regulation.

We have seen how the sex trade industry plays a significant role in the problem of women's rights, especially with regard to the global HIV/AIDS crisis, but how about the role that religion plays? The full picture, which for Thailand includes a discussion of how Buddhism, the dominant religion, plays an indirect role, is rarely depicted. Thai Buddhism contributes by defining women as unable to attain enlightenment in the female body and by not providing the same religious outlets for women that men are granted, 
therefore indirectly encouraging sex trade work. Buddhism's inherent position on matters of this-world and how its lack of social concern serves to circumstantiate the exploitation of the sex trade will also be highlighted. How and why this occurs in Thai society will be considered from several perspectives and will be discussed in great detail in the succeeding chapter on Buddhism's involvement with the politics of the sex trade. 
CHAPTER FOUR

\section{BUDDHISM'S CONNECTION TO THE SEX TRADE}

\section{Background}

Describing how Buddhism is indirectly involved with the politics of the sex trade industry in Thailand is complex, yet I am not the first to connect the two. ${ }^{73}$ In this thesis, the relationship will be defined as rooted in the issue of gender. I focus on how Thai Buddhist society views women with respect to prostitution and how Thai Buddhism views women themselves. On a fundamental level, it is important to bring Buddhism into the discussion, especially on gender, because Buddhism is very central to Thai people. It plays a crucial role in forming their cultural or national identity because of the intimate relationship Buddhism has with the government. This is not to say that all Thais are Buddhist and that all matters of Thai culture should be discussed in Buddhist terms, or that Buddhist texts and rituals are the only way a Thai person relates to Buddhism. ${ }^{74}$ However, if we were to continue without inviting Buddhism into the conversation, we would not get the full picture regarding the Thai case. As this is a delicate matter, I am not suggesting that Buddhism is the only factor to be considered with regard to the sex trade industry, but I do argue that it plays a significant role in the continued development of the sex trade. Wherever possible, I will cite directly from the Buddhist texts; otherwise, I will make reference to either native Thai or farang (Thai word for foreign) Thai and Buddhist scholarship. This is the case because the methodological approach to this study

\footnotetext{
${ }^{73}$ Scholars who study this issue will be highlighted in this chapter.

${ }^{74}$ Thai Buddhism is understood to include elements of animistic spirit worship as well as Brahmanical Hindu beliefs.
} 
involves reviewing important scholarship concerning three areas of interest - (1)

prostitution; (2) mae chis; and (3) bhikkhunis, as discussed in Chapter One - rather than a textual reading or direct analysis of the Buddhist scriptures.

In this chapter, Buddhism's shaping of the societal view of women and the negative impact of the Buddhist concept of merit-making in Thai society will be the principal conditions discussed that show how Buddhism is indirectly connected with the sex trade in Thailand today. To begin, the most frequently cited reason why Buddhism is said to encourage the practice of prostitution is the fact that the Buddhist institution does not actively fight against it, and thus passively condones it. Not only does Buddhism in Thailand ignore the prostitution problem by not banning it, but not condemning prostitution allows it to continue. Furthermore, Buddhism has permitted its concept of merit-making to be used to justify prostitution. The prostitute whose work supports her family earns her merit for filial sacrifice, and her family members who donate part of her proceeds to the temple also earn merit for themselves.

Thus, Thai Buddhism helps to support and somewhat sustain the sex trade industry today by not only co-existing with it, but also permitting it to be conflated with the acquisition of religious merit. Buddhism's failure to deal with the situation, both socially and religiously, has enabled the trade to thrive.

Why is this the case, since Buddhism usually addresses issues of morality and speaks against injustice and social inequality? Perhaps we could look at this issue with two points in mind. First, because Thailand does not enjoy the same level of religious plurality as Western nations do, Thai society is not suited to address human rights issues. Also, perhaps because Thailand does not practice the separation of sangha and state, 
Buddhism is granted special privileges. These privileges allow for the lines between religious and social spheres to become blurred, which impacts the way the attainment of merit in the Buddhist religion is affected by, and in turn affects, social problems like prostitution. Either way, it is safe to say that Buddhism does not do all it could to ameliorate the problem because it does not adequately confront it.

As mentioned earlier in Chapter Two, Buddhism enjoys a symbiotic relationship with the state and, therefore, is granted many privileges that other religions in the kingdom do not enjoy. This kind of power allows Buddhism to benefit from many aspects of the Thai state, one being the tax revenue gained by the infamous sex trade industry. In a documentary film by Mattani Rutnin regarding child prostitution in northern Thailand, a monk points out that a seven-story building on the monastic premises was paid for by donations from prostitution. ${ }^{75}$ Although this example directly illustrates the role of Buddhism with regard to merit, since the laity who donate money to the temple accumulate merit for their actions, it also highlights how the Buddhist institution is silent in its response to the practice. ${ }^{76}$ This is the case because the monastic institution accepts the donations, as they should, but does not address the issue of how the lay community is generating the money, even though it clearly knows how the money is earned. This is an example of how Thai Buddhism helps to support the sex trade practice. There seems to be a contradiction in the Buddhist approach. One of the first sermons of the Shakyamuni Buddha, the Four Noble Truths (which includes the Noble

\footnotetext{
${ }^{75}$ Penny Van Esterik, Materializing Thailand (Oxford, UK: Berg, 2000), p. 86.

${ }^{76}$ That is, Buddhism is not silent about mentioning the sex trade in general, but is silent regarding how the Buddhist institution responds socially to the sex trade industry.
} 
Eightfold Path), dedicated an entire pathway to explaining how one should live. This pathway is known as the path of Right Livelihood and suggests,

one should abstain from making one's living through a profession that brings harm to others... and should live by a profession that is honorable, blameless and innocent of harm to others. ${ }^{77}$

But how is "harm" actually defined? In Thailand, it is expected that if one is a lay

Buddhist, one generally follows and adheres to five main precepts: do not lie, do not kill, do not engage in sexual misconduct, do not take intoxicants and do not steal. This is further elaborated by the Eightfold Path's description of Right Action, which aims at promoting moral, honorable and peaceful conduct. It admonishes us that we should abstain from destroying life, from stealing, from dishonest dealings, from illegitimate sexual intercourse and that we should also help others to lead a peaceful and honorable life in the right way. ${ }^{78}$

Nevertheless, to say that one should not engage in sexual misconduct or refrain from illegitimate sexual conduct creates a problem, since it does not ultimately define what "misconduct" actually is, or what kind of activity is illegitimate. Van Esterik adds, ${ }^{79}$ unchastity or unlawful sex breaks the third of five precepts that laity undertake to observe. But the third precept is interpreted by many Thai men as a promise not to commit adultery- that is, not to have sex with someone else's wife, a very narrow definition of unlawful sex. ${ }^{80}$

${ }^{77}$ Walpola Rahula, What the Buddha Taught (New York: Grove Press, 1959), p. 47. ${ }^{78}$ Ibid.

${ }^{79}$ This data is based on extensive field research conducted by Penny Van Esterik, a leading scholar of Thai anthropology. Much of her work is based on the nature of Thai religious practice. For a critical Thai native's view on the relationship between the sex trade and Buddhism in Thailand, see Chatsumarn Kabilsingh, Thai Women in Buddhism.

${ }^{80}$ Van Esterik, p. 87. 
Van Esterik even goes further in a footnote to this passage by stating that,

a Thai man who identifies himself as a moral Buddhist said he always asked prostitutes if they were married, and chose another if they replied that they were married. A socially engaged Buddhist would consider that having sexual relations outside the context of love, responsibility, and respect breaks precepts, whether or not such behavior is proscribed in the texts. ${ }^{81}$

Here, she explains that although a Thai male may seem to be morally conscious, he may not be embodying the real essence of the Buddhist ideal. This is so because the Buddhist teachings of the Four Noble Truths and the Eightfold Path remain obscure to the majority of Thai Buddhists, although it does shape their consciousness, provide a worldview, and act as way to legitimatize social relations.

Van Esterik also quotes Troung, a Thai native, who assumes, "Buddhism is not cognitively salient to Thai Buddhists, yet looks to Buddhism to explain the status of Thai women and the existence of prostitution." 82 It seems quite obvious that there is a high degree of ambiguity surrounding how lay Buddhist teachings are interpreted and practiced amongst the Thai Buddhist population, which can also include how the monastic community ascertains their own definitions.

The way prostitution is spoken of in parts of the Buddhist Vinaya ${ }^{83}$ suggests another side to this argument, one in which prostitutes are not necessarily viewed negatively by Buddhism. Passages taken from various parts of the Vinaya texts, the

${ }^{81}$ Ibid.

${ }^{82}$ Ibid., p. 91 , n. 8.

${ }^{83}$ There is not one specific passage or chapter in the Vinaya texts which can be cited here, but rather several mention between seven and ten kinds of wives and how they are defined. See V., iii, 139,140; M. i, 286; and A. v, 264 as quoted by E. M. Hare, trans., The Book of Gradual Sayings Vol. IV (Oxford: Pali Text Society, 1995), pp. 56-58. 
Anguttara Nikaya and the Patimokkha, help to illustrate this. Perhaps the monastic institution of Thai Buddhism obtains comfort with the sex trade industry by seeking guidance in the Buddhist texts, as well as by staying true to the example of the Buddha himself and how he straightforwardly dealt with prostitutes. The Patimokkha Laws of the Buddhist Vinaya can be interpreted to permit prostitution because it mentions ten kinds of wives, which includes those to be enjoyed or used occasionally and those who are temporary or momentary wives.

As Murcott points out, they are: (1) dhanakkita--a woman bought with money for the purpose of sexual pleasure, (2) chandavasini - a woman kept for passion and most likely for love, (3) bhogavasini - a common housewife, (4) pattavasini - a previously poverty-stricken woman who lives as a wife because she is provided with clothing, (5) odapattakini - a wife who provides water and is also typically in love, (6) obhatacumbata - a woman who previously held burdens, like bundles of sticks on her head (cumbataka), (7) dasi - a slave woman made to be the wife of her master, (8) kammakari-a servant woman made to be the wife of her owner, (9) dhajahata - a woman obtained by force to be the wife of her captor, and (10) muhittiya - temporary or momentary wife. ${ }^{84}$ This kind of systematic categorization concerning wives implies that there is a lack of commitment from the male side of the marital relationship, and that sexual promiscuity is sanctioned rather than disapproved of. This example of the Buddhist Vinaya and its description of ten kinds of wives also "reflects on the recognition of the functionality of women's social roles," implying that prostitution is accepted by

\footnotetext{
${ }^{84}$ Lucinda Joy Peach, p. 219. For further reading see Susan Murcott, First Buddhist Women: Poems and Stories of Awakening (Berkeley, CA: Parallax Press, 1991), p.110.
} 
Buddhist definition. ${ }^{85}$ Here, women's social roles are undermined by the implication that a sex trade worker is an acceptable or even respectable position for women in Thai society to have. This kind of discrimination against women is similar to what was discussed earlier in Chapter Two under the section, Women's Roles in Society.

Another religious argument in favor of prostitution is based on the view that sex is not a sin for Buddhism, but rather that sexual craving is an example of tanh $\bar{a}$ (thirst) which is an expression of avidya (ignorance) because it is a part of the material world. The reason why prostitutes are not viewed in a negative way in the modern Thai view, which derives from the Buddhist scriptures, is that their impurity is considered karmic impurity and not sexual impurity. There is a Jataka Tales story about the courtesan Ambapali found in the Canto XIII, Psalms of About Twenty Verses, LXVI. ${ }^{86}$ After she gives birth to a son who later became one of the disciples of the Buddha, Ambapali enters the Buddhist order herself to ultimately achieve arahatta status, considered a lower level of enlightenment for a female nun. No condemnation of prostitution is evident from the story, which puts forth the idea that prostitutes can improve their negative kamma sufficiently so that they, too, can achieve enlightenment. This story can also be interpreted by Thai Buddhists as sanctioning the overarching practice of the sex trade industry, as well as justifying an individual's Buddhist's participation in it, although Buddhism historically is not known to condone prostitution. Rather, Buddhism allows one to reject one's previous lifestyle and repent for sins. However, in order to do so, it is

\footnotetext{
${ }^{85}$ Thanh-Dam Troung, Sex, Money and Morality: Prostitution and Tourism in South-East Asia (London: Zed Books, 1990), p. 136.

${ }^{86}$ See Rhys Davids trans., Psalms of the Early Buddhists I (Oxford: Pali Text Society, 1994), pp. 120-125.
} 
imperative that the former prostitute discontinue sexual relations while holding the status of being ordained or, at the very least, as a lay follower accept the role of mother in its aspects of reproduction and household responsibility. ${ }^{87}$

In the Buddhist scripture, Anguttara Nikaya Ekadassa Nipata, Metta Sutta, the concept of karunā bhävanā (the development of compassion) is attributed to how the Buddha allowed both prostitutes and murderers to reform their character by not condoning their behavior, but rather allowing for their repentance. This teaching is regarded as the way of loving-kindness, and is thus the proper way to go forth as a Buddhist in this world. One may translate this teaching to mean that the Buddhist path allows for immoral people like prostitutes and murderers to gain karmic rehabilitation through its path of Right Thought and Right Understanding as the wisdom of Buddhist truth, while simultaneously cultivating the values described by the way of Right Action and Right Livelihood. These values include acting properly in the world by not stealing, lying, or killing, and by refraining from occupations which may ask for one to go against the Noble Eightfold teaching. These kinds of people should not be excluded from receiving Buddhist training, regardless of what they have done in their past.

Although some aspects of the way Buddhism can be seen to view prostitution are unclear, Van Esterik claims there is no ambiguity surrounding the way both popular and canonical Buddhism describe the punishment due adulterers. Based on field research conducted at Wat Phairongwua in Suphanburi Province, she states, "the classification of

${ }^{87}$ Ibid., p. 137. 
sexual acts and demeritorious consequences are represented in giant tableaux depicting in gruesome details the hells occupied by adulterers. ${ }^{" 88}$ She continues,

auxiliary hells numbers 13,14 , and 15 are reserved for men and women who commit adultery with other men's wives or women who betray their husbands...bodies stabbed with lances until they are torn into small pieces, blood and pus flowing out; bodies crushed by fiery red iron mountains, pressing their bodies many times in the same way that sugar cane is pressed; bodies hung upside down into a pit, beaten with fiery red iron clubs; bodies chased up and down kapok trees, torn by flaming thorns." 89

These descriptions are said to be representative of both sides of Buddhism (how either prostitution is tolerated and allowed, or spoken badly of), and that there is no ambiguity regarding the consequences. However, as she notes, the descriptions are still not enough to deter society from engaging in this type of extra-marital encounter. Here lies the unbalanced perspective of women's sexuality, derived from both the Buddhist texts and the contemporary Thai Buddhist understanding, which is that adultery is strongly criticized but sex with a prostitute or unmarried woman is not. It is my contention that patriarchal values brought into Thailand from China and India, as well as some that may have existed prior to external influences, have helped to encourage a favorable attitude toward prostitution, which has ultimately led to its tolerated overuse today. This comment by no means suggests that Buddhism causes prostitution, but rather that Buddhism is well aware of the situation yet does not do enough to eradicate the problem. To elaborate further on these ideas and to demonstrate in more detail how Buddhism is indirectly involved in promoting prostitution, let us now turn to a more critical analysis of women and Buddhism.

\footnotetext{
${ }^{88}$ Van Esterik, p. 87.

${ }^{89}$ Ibid.
} 
Buddhism is widely acknowledged and favorably known for its tolerance, both in the West and in the East where it originated. This tolerance is considered to include the issue of women's rights, since the Buddha was known to have allowed women the ability to be ordained as bhikkhunis. Both positive and negative arguments on the subject of women and Buddhism can be made in regard to the Thai case, as well as for any other majority Buddhist country. Here, I will provide two analytical approaches from positive and negative sides by referring to foreign Buddhist scholarship as well as native Thai Buddhist criticism.

On the positive side, Rita Gross has completed a feminist revalorization of Buddhism by concluding that no Buddhist teachings support gender inequality or gender hierarchy, although the concept of kamma was reinterpreted to justify male dominance. Buddhism is androcentric but not misogynist. What she means is that women are treated as objects to be defined, classified, and debated by men, creating a problem because they are exterior to the definition of mankind. Women, in her opinion, are robbed of their identity because they are neither sought nor listened to in this process. ${ }^{90}$

In her "revalorization" of Buddhism, which understands how Buddhism is related to feminism, Gross suggests that the following must be undertaken: (1) the study of the historical record regarding women and the image of women in Buddhism, (2) an analysis of the key concepts of the Buddhist worldview vis-à-vis gender and gender privilege, and

${ }^{90}$ See Rita M. Gross, "Feminist Revalorization of Buddhism," in Feminism and World Religions, eds. Arvind Sharma and Katherine K. Young, 78-109 (Albany, NY: State University of New York Press, 1999), p. 107, n. 4. 
(3) a reconstruction of both Buddhist thought and Buddhist institutions in light of feminist values. ${ }^{91}$

In her study, Gross has brought two generalizations to light. The first focuses on the reality that every period of Buddhist history illustrates at least two views regarding women. On the one hand, women are conceived of as being more emotional and more sexual than men, and incapable of significant progress on the Buddhist path. A different view argues that women are not inherently inferior to men in their ability to achieve calm and insight required to attain nibbāna. If there are traditionally two completely opposite views regarding women in Buddhist history, including a positive one, Gross wonders, why is it that women are seen today as a hindrance to enlightenment? If there are both negative and positive ways to view women from the Buddhist perspective, women have far more choices than previously thought, and therefore are not in a position to be undermined or taken advantage. According to Gross's analysis, the role of women is not quite as limited as might seem to be the case.

The second generalization is based on her examination of all three of the Buddhist schools: Theravada, Mahayana, and Vajrayana. She concludes that the bias against women becomes less tolerated as each new school has developed through the course of history. This is to say that as the Buddhist religion has changed, so has its understanding of the worth of women. ${ }^{92}$

\footnotetext{
${ }^{91}$ Ibid., p. 81.

${ }^{92}$ Gross continues to say that this pattern differs significantly from other world religious traditions by suggesting that many do not see women in a favorable light.
} 
Although Gross' remarks reference Buddhism in general, if her generalizations were to be applied to Thailand as a predominantly Buddhist nation, Thailand would fall short of expectations, largely because it is a Theravada country. Since the Theravada lineage is the earliest form in Buddhist history, it reflects more of a prejudice against women. Shakyamuni Buddha allowed women to be ordained during his lifetime, yet he also claimed that the Buddhist religion would fall victim to having allowed them into the monastic community by stating, "if permission were given to women to leave the home and to enter the homeless state under Buddhist doctrine, Buddhism could stand fast for only five hundred years instead of two thousand years." 93 The warning suggests that the Buddha was aware of the inherent gender bias that existed in India during the $5^{\text {th }}$ century $\mathrm{BCE}$, and that he was concerned about the livelihood of women and how they would be treated and viewed. Also, he was worried about women becoming a distraction and a hindrance to the monastic order, as previously described in Chapter One. The above quote also infers that the Shakyamuni Buddha was concerned with the reproductive aspect of women, because without their ability to reproduce, there could be no new life and ultimately no Buddhist sangha.

By considering this example, Thai women are viewed as most valuable for their responsibilities of being mothers, especially because of their ability to produce male offspring who can be raised under the Buddhist tradition and one day be ordained as bhikkhus. Along the same lines, women in Thailand are forbidden from receiving ordination as full bhikkhunis. The Thai Buddhist institution claims that since the bhikkhuni lineage never reached Thailand historically, this status can never be achieved

93 Troung, p. 136. 
in Thailand. Some Thai women currently are receiving higher ordination precepts from Sri Lanka, a Theravada Buddhist country, while others have ventured to Mahayana countries like Taiwan for ordination. This topic will be considered in more detail in Chapter Six, The Bhikkhuni Struggle in Thailand.

Gross's first generalization regarding the ambiguity of the Buddhist view of women throughout its history (early history denies women privileges, whereas latter history grants them ordination) may help explain modern Thailand's view of women as having second class status. This view is illustrated by the way the Buddhist monastic institution in Thailand is silent regarding the sex trade industry, although it receives donations from the laity who have earned their monies through prostitution. This stance, in essence, supports women's right to use their bodies in an immoral and non-Buddhist way, and allows them the benefits of acquiring good kamma without having to give up their illicit behavior.

In accord with this, women are seen as being incapable of reaching enlightenment unless they are reborn as a male. At the same time, some women in Thailand are viewed as being spiritually superior to men, especially in their attempts at enlightenment. This will be discussed further in Chapter Five, the Thai Mae Chi Position, which illustrates how there are mae chis in Thailand today who are masters of meditation techniques and who even host their own quite popular television series on Buddhist meditation.

In the end, Gross's positive view of women in Buddhism does not fall in line with how Thai women are treated under the Buddhist system today, because women are still highly disregarded. The chapters to come will highlight the problems women are having recently with regard to higher ordination and with their status in Buddhism. 
To add another positive view regarding women and Buddhism, let us turn to the analysis of Thai scholar Suwanna Satha-Anand. Her approach insists that a feminist reinterpretation of key Buddhist passages can help change the cultural conditions that contribute to the pervasive problem of female prostitution in Thailand. ${ }^{94}$ She discusses how national and global "pull" forces play a role in the flesh trade, while arguing that "push" forces are also evident with regard to how traditional religious values are used to justify the subordination of girls. It is her contention that Buddhism "can and should do something to help remedy the situation," be an active party to the crime, we must still ask whether it has done enough to prevent some of the cases from happening." 96

Much like Gross, Satha-Anand believes that feminism is critical to the reinterpretation of Buddhist texts, although she adds that the interpretation needs to come from the inside, and not from outside Western onlookers such as scholars and researchers. In her view, this reevaluation needs to be achieved in local schools by showing plays that reeducate Thai society from the ground up on new interpretations of key Buddhist stories. Ultimately, this all should be done with the help of the Buddhist religious institution. By conditioning all of society and illustrating how it positively recognizes women's human rights, Buddhism can help to elevate the cultural standing of women and therefore aid in

\footnotetext{
${ }^{94}$ See Suwanna Satha-Anand, "Looking to Buddhism to Turn Back Prostitution in Thailand," in The East Asian Challenge for Human Rights, eds. Joanne R. Bauer and Daniel A. Bell, 193-211 (Cambridge, UK: Cambridge University Press, 1999).

${ }^{95}$ Suwanna Satha-Anand, p. 194.

${ }^{96}$ Ibid.
} 
minimizing their exploitation via the sex trade industry. Additionally, Satha-Anand contends,

certainly the positive resources exist within Buddhist teachings- the affirmation of women's capacity for Enlightenment, for example, along with the principles of respect and compassion for others-to contribute to such empowerment and reversal of the cultural images of women's inferiority. ${ }^{97}$

This point progresses the idea that women need to empower themselves to become more culturally aware of their human rights under Buddhism. She claims that the five precepts the majority of Thai Buddhists adhere to are in themselves a protection of human rights. As mentioned earlier, these Buddhist teachings (The Four Noble Truths and the Five Precepts) are important to everyday life in a predominantly Buddhist nation like Thailand, and thus must be included in the discussion/reinterpretation. Also, it would be through a feminist reinterpretation of key Buddhist stories like the popular Jataka Tales, ${ }^{98}$ that the bulk of Thai society could be led to understand that Buddhism actually addresses women's rights, and that it does so in a positive way.

The most popular of the Jataka Tales in Thailand is that of Queen Madsi. She is revered as the ideal woman because she sacrifices all, including her children, to advance the religious goal of her husband. Her sacrifice is normally viewed as an example of women's inferiority. However, Satha-Anand suggests it should be reinterpreted to mean the opposite. Since Satha-Anand is Thai, and speaks critically of her own tradition, she is highly regarded for her scholarship which focuses on how prostitution is affected by its relation to Buddhism. Since this issue is quite sensitive, and one that many Thais care to

${ }^{97}$ As cited by Peach, p. 222.

${ }^{98}$ Davids, pp. 120-125. 
not have unearthed, Satha-Anand being of Thai descent helps to bring attention to the matter by offering a critical insider's view on the issue. Because she is Thai, she is less likely to be attacked for her stance in comparison to a Westerner who makes a similar claim. Because of this, her description is noted here for its authenticity and concern for the future of Thai women and Thai culture in general.

Thus, Satha-Anand, like Gross, proposes a reinterpretation of the Buddhist texts because it is necessary for women to be able to see how their human rights are protected under the sacred scriptures. She addresses women's rights in commenting on how Buddhism can play a direct role in providing a solution for the prostitution crisis. SathaAnand claims that the extent of prostitution is a problem in Thailand today because it is a commonly held view that the frequenting of prostitutes is actually preferred to the alternative of having minor wives. This is because prostitutes are seen as less of a threat to the family, the household income, and the major wife's social face. Buddhism can help to correct this attitude.

After evaluating how Buddhism is seen to be positive in its treatment and definition of women, now let us consider some opposite views. On the negative end, Khin Thitsa, another Thai native researcher, suggests:

Thai women had a strong position despite, not thanks to, Buddhism. Buddhist philosophy importantly denigrates the de facto position of women, propagating an image of her as inferior and dangerous, which has been instrumental in denying her legitimate power in the form of bureaucratic or official position, while allowing her unrestricted access to the realms of labor and the economy. ${ }^{99}$

\footnotetext{
${ }^{99}$ Khin Thitsa, "Nuns, Mediums and Prostitutes in Chiengmai: A Study of Some Marginal Categories of Women," in Women and Development in South-East Asia I Occasional Paper No., eds. Khin Thitsa and Signe Howell, 3-34 (Canterbury, UK: Centre of South-East Asian Studies, 1983), pp. 9-10.
} 
She argues that along with Hindu influences (both of which are considered outside foreign religions), Buddhism devalues the role of women because it condemns them to an inferior status by under-appreciating their contributions to society: "The negative construction of female nature means that women have little choice but to assume marginal roles in society, such as prostitutes, spirit mediums, and nuns." ${ }^{100}$ It is Buddhism's influence on Thai values, perceptions, and social relations that, she claims, is the major factor contributing to the devaluation of women.

In addition, Thitsa's unfavorable view of Buddhism includes a discussion of how women's monastic roles are viewed in Thai culture, since Thai Buddhism denies women the privilege of higher ordination, a path which grants many poor, male villagers access to education and to a higher social status. However, it is also Buddhism's ambiguous stance regarding the position of the nine precept nun, the Thai mae chi, that causes Thitsa to conclude that "in Buddhism women are second-class citizens and that their inferiority has been strengthened by Thai government control of Buddhism. By becoming prostitutes women fulfill cultural expectations that they are lustful, seductive, corrupting and greedy." 101

Many Thai women become nuns and prostitutes because they consider themselves to be fallen women and unworthy of other social positions. It is Thitsa's understanding that prostitution is degrading, and that only women who are already impoverished and legally and religiously degraded by their inferior status would be willing to become

${ }^{100}$ Nicola Tannenbaum, "Buddhism, Prostitution and Sex," in Genders and Sexualities in Modern Thailand, eds. Peter A. Jackson and Nerida M. Cook, 243-260 (Chiang Mai, Thailand: Silkworm Books, 1999), p. 246.

${ }^{101}$ Ibid., p. 249. 
prostitutes. She approaches her analysis of Buddhism based on its interpretation and validation of Thai social conditions, rather than from a discussion of how Buddhist scriptures actually defines women.

Yet another view which emphasizes the negative implications of Buddhist scripture is the critical approach of Thai native and Buddhist scholar, Chatsumarn Kabilsingh. From her analysis of the texts as being corrupted, she concludes that women in Thailand have been cheated out of higher bhikkhuni ordination and out of the respect they deserve for their spiritual abilities to obtain enlightenment. She suggests that this stems from two points regarding the First Buddhist Council. Kabilsingh writes, "although there were a number of enlightened bhikkhunis, highly praised by the Buddha for their knowledge of the Vinaya, skill in giving Dharma talks, and attainment in wisdom and spiritual powers, none were invited to the Council." 102 She claims this shows that the Bhikkhu Sangha had a prejudice against the bhikkhunis, and therefore did not want them to be present when the Buddha's teachings were to be carefully discussed and documented. If women were not present to share in the First Council, it is fair to say that their point of view and actual experiences were not taken into account. In effect, they were completely overlooked, and one could even argue, entirely disregarded. Kabilsingh adds, "the Buddhist texts are primarily androcentric - male centered. They were recorded by monks, in the interest of monks." 103 This perception can be compared to the modern Thai case, since women currently are denied access to higher ordination. One could argue

${ }^{102}$ Chatsumarn Kabilsingh, Thai Women in Buddhism (Berkeley, CA: Parallax Press, 1991), pp. 22-23.

${ }^{103}$ Ibid., p. 25. 
that because the historical example does not contain a more favorable opinion of ordained women, today the Buddhist institution follows suit. If women had been allowed to join the First Council, they may have had a better chance of retaining the positive status awarded to them by the original teaching of the Buddha.

A second point is made by Kabilsingh regarding how Ananda, the Buddha's closest attendant, was accused by other monks of having committed a crime for encouraging Shakyamuni Buddha to accept women into the monastic order. She writes:

even though Ananda made it clear that he felt he had committed no wrongdoing, he confessed to the offense in order to save the Sangha from further disagreement and possible schism. This event suggests that, among the hundreds of arahats in the First Council of the Sangha, many strongly opposed the establishment of the Bhikkhuni Sangha. Unable to go against the decision of the Buddha during his lifetime, they raised the issue immediately after his Parinirvana. ${ }^{104}$

It seems that in the Indian Hindu system, a negative view of women was culturally dominant. It is easy to see how this view can also be considered to be part of Buddhism, since the religion arose from the Indian tradition. Although the Buddha fought for the rights of women, showing that he was against the cultural definition of his time, this view does not inevitably translate to all Buddhist social levels today. Dating back to the early teachings of Buddhism, it is likely that some so-called members of the Buddhist tradition believed that they were able to overcome prejudice against women. However, they may not actually have lived this out because the underlying cultural bias against women was so strong.

Kabilsingh also points out the importance of the Gurudhamma (the eight rules that all bhikkhunis must follow), which can be found in the tenth Kullavagga of the

${ }^{104}$ Ibid., p. 23. 
Vinaya text titled the Duties of the Bhikkhunis. ${ }^{105}$ The rules range from requiring senior nuns to pay homage to new monks, regardless of the length of time a monk has been ordained, ${ }^{106}$ to stating that nuns cannot criticize or speak badly about a monk, although monks retain the right to criticize nuns. Her opinion is that the rules were not meant to oppress women, as Western scholars often think, but were meant to protect them:

in order to facilitate their acceptance into the Order...to assure the bhikkhus that they had nothing to lose by the admission of women. The Bhikkhuni Sangha was thus required to adopt the Gurudhamma.

Although the Gurudhamma can be viewed in a negative way, Kabilsingh offers another interpretation. She suggests that these rules were enforced and applied in order for women to be safeguarded, so that a brother/sister relationship could be established between bhikkhus and bhikkhunis. Her overall understanding of Buddhism is that it is not necessarily oppressive to women. Rather, some of the circumstances surrounding women and their lack of being completely accepted after the Buddha's death remain questionable and have problematic implications for their role in society today. Although she does not blame Buddhism for the social problems facing Thai women currently, Kabilsingh does hold Buddhism accountable for some things like the corruption of the texts, which she feels has had an effect on how Buddhism is currently being practiced. There is yet another view regarding women in Theravada Buddhism addressing the issue of their

${ }^{105}$ See T.W. Rhys Davids and Hermann Oldenberg trans., "Vinaya Texts Part III The Kullavagga IV-XII," in The Sacred Books of the East, ed. F. Max Muller, 300-425 (Delhi: Motilal Banarsidass Publishers, 1965, pp. 322-324.

${ }^{106}$ This condition is viewed as a reversal of the usual hierarchy of the Sangha since seniority is based on the length of time one is ordained. This rule is the one most often cited by Western scholars to be taken out of context when claiming Buddhism treats women unfairly. 
ability to reach enlightenment that will be examined next with respect to the role meritmaking plays in Thailand.

\section{Thais and the Concept of "Merit-Making"}

As defined in Chapter One, merit (puñña) is a means by which Buddhists can build good karma from acts of generosity. Traditionally, all Thai men were ordained as bhikkhus, if even for a temporary period in order to gain merit for themselves as well as for their families. ${ }^{107}$ Women in Thailand, however, are not provided with this same opportunity, thus limiting their access to acquiring merit. This is one way that the Buddhist doctrine of merit-making is connected to the gender-biased monastic establishment that is said to enable the flourishing of prostitution. ${ }^{108}$ The conditions surrounding how a Theravada Buddhist generates and accumulates merit in Thailand will be considered here as one factor supporting the sex trade industry. However, before examining this, let me introduce a similar situation occurring in a neighboring Asian Buddhist country, Japan.

Similar to Thailand, Zen Buddhism in Japan is considered "discriminatory" because of its practice of kaimyō (Zen Buddhist posthumous names) and how they are given to the deceased based on social rank and the amount of donation made to the Buddhist temple. ${ }^{109}$ The Japanese case is relevant because, as Steven Heine states, "a

107 The act which generates merit is usually done by the lay practitioner for their benefit, or done by them so that their actions can be dedicated to another person for the benefit of both.

108 Peach, p. 219.

109 See Steven Heine, Zen Skin, Zen Marrow: Will the Real Zen Please Stand Up? (New York: Oxford University Press, 2008), pp. 148-153. 
basic problem with the system is that the deceased's behavior in their lifetime seems to be of less importance than financial considerations or social connections harnessed at the time of death." $" 10$ This is related to the Thai case, because money donated to Buddhist temples is used in a polemical way to justify the accumulation of merit. Although different examples, both kinds of Buddhist tradition and practice, one in Japan and the other in Thailand, clearly deviate from the Buddha's teachings. This highlights how Buddhism's relationship with the government introduces both the tolerance of unacceptable practices and the suppression of the rights of the underprivileged.

Regarding the specific Thai situation, the way in which women generate merit is generally through the practice of giving dana in the form of money, food, and other provisions to temples and individual monks. Monks are considered to be "fields of merit," as the popular Thai phrase na bun indicates. Tavivat Puntarigivat, a Thai religious scholar states, "Na bun (field of merit in Thai) is a metaphor for Thai Buddhism which means that bhikkus are like fields (na), for which a Buddhist could throw seeds of merit (bun), so that they may yield the result of the harvest (merit)."111 Since women are denied access to higher ordination, their roles as Buddhist lay followers are limited. Thus they must find other ways to embody the Buddhist ideal. Usually this is done through either the lay position of frequenting temples and donating regularly or through the role of the semi-ordained mae chi. However, many women and young girls are currently being persuaded or even deceived into sex trade labor, which they see as an alternative means

${ }^{110}$ Ibid., p. 149.

111 Tavivat Puntarigvivat, "A Thai Buddhist Perspective," in What Men Owe to Women: Men's Voices from World Religions, eds. John C. Raines and Daniel C. Maguire, 211-237 (Albany, NY: State University of New York Press, 2001), footnote 7, p. 235. 
for acquiring merit. This seems to be a rather non-religious way to generate merit, but it is becoming more popular in Thai culture. ${ }^{112}$

In this section, one standpoint will be presented in an attempt to validate the above claim. Women in Thai culture are viewed as inherently impure and therefore not eligible for enlightenment, and are thus locked into degraded positions ranging from sex trade laborers to nuns as a means to generate merit for themselves and their family. The way this will be addressed is by isolating the issue surrounding women's non-admittance to the Buddhist monastic institution in Thailand.

Buddhism has played a significant role in shaping law, cultural frameworks, and social life in the kingdom of Thailand. It has done so because of its relationship with the Buddhist Sangha as a religious organization and with the state on the political level. This association has allowed the Buddhist institution to be involved in many areas of Thai social life. Although not all Thais are Buddhist, the conditions for how the majority of women are to be viewed are seen through a Buddhist lens. Typically, this view regards women as impure because of the notion that having been born a woman is a result of negative kamma. This belief has even been documented throughout Thai history, as inscriptions on temple walls in $15^{\text {th }}$ century Thailand have noted. ${ }^{113}$ For example, a Queen Mother requested that the following inscription be made on her behalf, "by the

112 The mae chi role was traditionally viewed as inferior and was not typically desired. However, today there are mae chis who are working towards elevating their status via the Thai Mae Chi Institute, which is allowing mae chis to acquire access to education and training.

${ }^{113}$ Truong, p. 135. 
power of my merit, may I be reborn a male..."114 She considered herself to be pious enough to have earned a future rebirth as a male because of her very generous offerings to help construct temples throughout her city. This is one way that we see how the doctrine of kamma becomes an important tool for the rejection of the female sex in Thai culture. Today, this idea has gone even further, as Troung suggests, since it is a common belief in Thai society that only through rebirth as a man can a woman be ordained and therefore achieve the ultimate goal in Buddhism of attaining enlightenment.

Another example depicts one of the most highly respected Thai female traditions as a means for acquiring a high amount of Buddhist merit through a woman "giving" a son for ordination. However, this could only be done if a woman takes on the duties of a wife-mother. Men in Thai society are generally viewed as being concerned with becoming at least temporarily ordained. Kirsch states:

because men can achieve the highest Buddhist role their relationship to Buddhist norms and values is more intense and they must be more sensitized to them than women. Because women are inextricably linked to the world the intensity of their relationship and their sensitivity to Buddhist values and norms is qualitatively different from that of men. ${ }^{115}$

Because of the role Buddhism plays in Thai culture, women are consistent in their diligence towards performing meritorious acts, since they are culturally viewed as needing the merit more than their male counterparts.

Since women cannot be fully ordained in the Thai Buddhist tradition, they have to find other options that are generally accepted by Thai society and readily available for their use. One said option is to join the sex trade labor force. However, this option is not

${ }^{114}$ As cited in Troung, p. 135.

${ }^{115}$ Kirsch, p. 27. 
always a woman's personal choice, as it can be brought on by other factors. Puntarigvivat claims that in rural northern Thailand, families who fed him while he was an ordained bhikkhu also sold their daughters into prostitution. There are even stories of young girls stolen from their rural villages and taken to Bangkok or Pattaya to work as prostitutes. ${ }^{116}$ Typically, the selling of girls into prostitution is viewed as a necessary sacrifice and a means for many poor villagers to rise above their impoverished situation. Young women who have been sacrificed in this way see their situation as an acceptable means of filial piety and therefore do not complain or reject their parents' wishes. In some cases, since the work is so lucrative, young women decide for themselves to choose this option, although they frequently send back money to their village families, which in turn is later donated to local temples. ${ }^{117}$ Hence, both the parents of prostitutes and the prostitutes themselves donate money to local Buddhist temples in order to gain merit for their offerings.

Traditionally in Thailand, the giving of a son for ordination served more than the purpose of acquiring merit. Since education was scarce, especially in the rural, underprivileged areas of pre-modern Thailand, education throughout the kingdom was linked to the Buddhist monastic community. Therefore, to be ordained as a bhikkhu provided a son with a formal education and granted merit for him and his family. It is important to add that this opportunity enabled the individual to rise out of his povertystricken lifestyle, since the temple would provide food, shelter, and other privileges.

${ }^{116}$ Raines, p. 63.

117 See Kabilsingh. 
Today the argument is made that if women were given the right to be ordained as bhikkhuni or even receive similar privileges under the mae chi, allowing women to be raised in a religious temple setting, the number of female prostitutes would be greatly reduced. Currently, there are about 300,000 ordained monks throughout Thailand, and although it is hard to accurately count the number of sex trade workers, the numbers are viewed as comparable, while sex workers are continually increasing, at the same time the number of monks stays about the same. ${ }^{118}$

As the following chapters will illustrate, recent scholarship is highlighting how Buddhist women are becoming more empowered in their attempts at changing the current system in Thailand. In Chapter Five, the conditions surrounding the ambiguity of the Thai mae chi position will be considered, while Chapter Six will introduce the struggle for the legitimation of a Thai Bhikkhuni Sangha.

${ }^{118}$ Kabilsingh, p. 84. 


\section{CHAPTER FIVE}

\section{THE THAI MAE CHI POSITION}

\section{Function in Society}

We have already seen how Buddhism plays a role in Thai society with regard to prostitution, but the ordained religious heritage of women within Buddhism has yet to be examined. It is the customary view in Thailand that women are prohibited from touching monks or even from sitting alone in a room with them. Although this is a matter of Buddhist Vinaya, the Thai Buddhist tradition has taken this idea to an extreme. As observed in both Thai Buddhist temples in Thailand and in South Florida, monks observe this precept with the utmost care. One local example was of how a young woman receives a gift from an elder monk. The monk does not simply place the object down so the woman can pick it up, but instead lightly throws the object into her hands for fear of contamination via direct contact. This is a rather regular occurrence for Thai bhikkhus.

These monastic regulations present a major challenge for women's access to Buddhist teachings. If women were provided with equal or even similar opportunities for ordination, some scholars argue that the number of female sex trade workers would dramatically decrease. ${ }^{119}$ Although this seems to be an easy solution to which Buddhism could contribute directly, the ambiguous status and lack of formal recognition of the Thai mae chi in Buddhist scripture and Thai law still remains, creating a major obstacle for women.

${ }^{119}$ For further reading see Monica Lindberg Falk, Making Fields of Merit (Copenhagen: NIAS Press, 2007) and Virada Somswadi, ed. A Collation of Articles on Thai Women and Buddhism (Chiang Mai, Thailand: Women's Studies Center Chiang Mai University, 2002). 
As defined in Chapter One, the mae chi is a five-precept, eight-precept, or nineprecept nun or female renunciant in Thailand. She has a shaven head, wears white robes, and lives within a monastery or nunnery. ${ }^{120}$ Mae in Thai means "mother," while chi refers to the ascetic way of life, as they are often viewed as "mothers in white," although they are not granted the high esteem given mothers in Thai culture. Mae chis are also known to follow a form of monastic life, but without any formal legitimation or lineage rooted in Thai law and Buddhist scripture. ${ }^{121}$ In addition, they are usually not the recipients of dana (donations) because of their lack of status, and thus are frequently denied privileges of almsgiving practices. ${ }^{122}$ Currently, Thailand has estimated the number of mae chis to be between 10,000 and $15,000 .{ }^{123}$ As one of the meritorious avenues of Buddhist spiritual practice, the mae chi position does attract followers, as it can offer a more challenging level of devotion than remaining a lay Buddhist. However, the kinds of women who are attracted to this path are not always spiritual at heart. Mae chi Khunying Kanitha Wichiencharoen, one of the founders of the Association for the Promotion of the Status

${ }^{120}$ The treatment and view regarding mae chis who reside in nunneries is far better than those living in wats (temples).

${ }^{121}$ It is well documented that the mae chi have existed in Thailand for over three hundred years, but they still lack many privileges awarded male Buddhist ascetics today.

122 This may depend on whether the women live in monastery communities or local nunneries. Typically, women in nunneries are provided with higher respect among their local village community and would generally be seen doing alms rounds.

${ }^{123}$ See Karma Lekshe Tsomo, ed., Buddhist Women and Social Justice (Albany, NY: State University of New York Press, 2004), p. 180; and Monica Lindberg Falk, "Thammacarini Witthaya," in Innovative Buddhist Women, ed. Karma Lekshe Tsomo, 61-71 (Richmond, UK: Curzon Press, 2000), p. 62. 
of Women (APSW), suggests that a reason why nuns are considered to rank low on the social ladder is because:

beggars have been known to pose as nuns, which has fostered in Thai minds, a skepticism of the latter. In addition, nunneries attract mostly chao ban (villagers) and not educated urban women and since the former are already a voiceless faction of society, it only serves to compound their low status. ${ }^{124}$

This is only one explanation for the existing discrimination that the mae chi face in modern Thailand. Other very commonly held views are that nuns choose this role in order to heal from a broken heart, suggesting that women are more concerned with being helped rather than giving help. An additional stereotype is that Thai nuns in temples are viewed as servants of the monks in the form of temple hands. These women cook, clean, and mend monks' robes, among other temple duties. However, the president of the Thai Mae Chi Institutite, mae chi Prathin Kwan-Orn, believes that this is a matter of choice, since many mae chis do not mind being subservient to monks. ${ }^{125}$ Personal observation during a trip to Thailand in the summer of 2004 suggested that many mae chis at Wat Paknam in Bangkok (one of the few Buddhist temples in the city that has a separate nunnery on the monastic complex which houses over one hundred mae chis) are very happy to cook and clean in exchange for room, board, and Buddhist consolation.

To go back to the reference made earlier about how Thai law and the Buddhist scriptures do not support the mae chi, it is important to understand that the nuns are neither considered upāsikā (laywomen), because they reside on temple premises and are known for their renunciate status, nor are they thought of as ordained members of the

${ }^{124}$ Somswadi, p. 72.

125 Ibid. 
Buddhist Sangha, because women are denied that lineage in Thailand. So technically, the mae chi are deprived of their civilian status, which takes away their right to vote since they are viewed as having renounced worldly concerns. To complicate matters, the nuns go without the many privileges that are awarded to bhikkhus, such as a half-fare discount on all public transportation in Thailand, free education, and even monetary donations from the laity. Although these privileges may not seem essential, their denial serves the purpose of adding to the mae chis' lower status because of the deficiency of community as well as Buddhist institutional support.

Kabilsingh suggests that, "marginalized, undereducated, and economically unsupported, mae chi are alienated in present-day Thailand." ${ }^{126}$ However, these views have been rapidly changing as a result of: the establishment of the first Buddhist school for girls, Thammacarini Witthaya in central Thailand in 1990; the lobbying for a Nun's Bill in 1996 and 2007; and the consecration of the first Buddhist College for Women, Mahapajapati Theri College in 2001. How these achievements have helped the mae chi movement in Thailand, and what their future goals are, will be considered in the following section.

\section{Recent Achievements and Goals for the Future}

Since there are approximately 300,000 Buddhist monks, over 150,000 female sex trade workers (although not all women are registered), and 15,000 Thai mae chis, it appears that just based on sheer numbers, men are more interested in undertaking the religious life. Perhaps this is the case in Thailand, given that men can be ordained for

${ }^{126}$ As quoted in Karma Lekshe Tsomo, ed., Buddhist Women and Social Justice (Albany, NY: State University of New York Press, 2004). 
temporary periods in an attempt to acquire Buddhist merit for themselves as well as their families, and due to the fact women are denied full ordination privileges. The Buddhist Sangha, Thai government, and wealthy lay practitioners fund the construction and maintenance of wats. An argument can be made that since women do not benefit from the same countrywide support, they have yet to establish the same magnitude of nunneries in the country. Also, considering that the status of the mae chi is so low due to lack of the Buddhist institution's support, why would one care to undertake the funding of such women?

For the past eighteen years, leading advocacy groups for women and local Thai women have been fighting for the rights of the mae chi. These women include not only everyday lay Buddhist followers who aspire to be mae chis, but also educated mae chis who seek further dhamma training and highly educated women who serve in positions in Thai society such as attorney. With these women fighting for mae chi rights during the last two decades, nunneries independent of temples have increased significantly. Today, according to the Thai Mae Chi Institute, there are an estimated 850 independent nunneries throughout Thailand. ${ }^{127}$ One benefit of the mae chi movement currently is that since they are not technically a part of the Buddhist Sangha administration, it is much easier for them to establish their own communities.

Although this seems to be a major advantage for the mae chi, it does not come without a negative side. The negative side is that since the nunneries could be established so readily, usually through funding and land donated by mae chis themselves or by their

${ }^{127}$ See Monica Lindberg Falk, "Women in Between," in Women's Buddhism, Buddhism's Women, ed. Ellison Banks Findly, 37-57 (Boston: Wisdom Publications, 2000), p. 40. 
families and other local supporters, individual nunneries are not necessarily connected to other mae chi organizations. The Thai Mae Chi Institute and the Nun's Bill are two measures whose goals are to unite the mae chi movement.

The Thai Mae Chi Institute has been an organization that seeks to address the mae chi's immediate needs, as well as to attain short term goals and define long term concerns. The institute was established in 1969 and came under the royal patronage of Her Majesty the Queen in 1972. The institute's goal is to provide a forum for Thai mae chis from all over the country and to work on the issue of mutual well-being and spiritual growth. ${ }^{128}$ Their main office is located in a temple in Bangkok, Wat Bowonniwet, which is the home of the current Sangharaja. Nevertheless, even though the institution has been around for thirty years, it has been moving slowly with regard to feminist activism. The institute only cares to give the mae chi more access to the already existing system and organization of Thai mae chis, and has not discussed the issue of reforming their status within the Buddhist framework.

The main goal of the institute is to help the mae chis develop both intellectually and spiritually. Educational training courses in practical and religious matters, as well as the Mae Chi Institute's meetings are organized from the main office in Bangkok. Books, clothes, and other necessary items are also sold there. The institute has over twenty branches throughout Thailand, spanning all major regions of the country. The national association is modeled after the Buddhist Sangha, which has a hierarchy consisting of a

${ }^{128}$ There are currently 580 nunneries in 47 provinces, registered with the Institute. 
supreme leader with organized offices on the regional, provincial, and district levels. ${ }^{129}$ Although the institute has been quite successful in uniting the mae chis and forming an identity for the nuns that is separate from lay practice, the organization has experienced one major setback, which is trouble with "false nuns."

The "false nuns" are women in urban areas who shave their heads and dress like mae chis in order to attract donations from people. The existence of these women has posed a major threat to serious mae chis and to the institute, and the problem has not been easy to solve. ${ }^{130}$ The way the Thai Mae Chi Institute has dealt with the predicament has proved beneficial for promoting the cause of the mae chi in general, but has yet to eliminate the "false nun" problem entirely. Their strategy includes implementing: (1) proper ordination procedure for all mae chis, (2) appropriate conduct among them, (3) religious practice, and (4) education. With these four principles in place, it becomes easier to distinguish the "false nuns" from the true mae chis. Adhering to these measures allows for mae chis to understand the nature of inappropriate behavior and therefore places a major obstacle in the path of the "false nuns." If mae chis follow the above rules, it makes it more difficult for any woman to impersonate the real mae chi. If women are forced to have a formal ordination procedure and be involved in both religious practice and study, "false nuns" can more easily be distinguished from the truly religious ones.

Even though the institute has provided the mae chis with many uplifting and beneficial tactics for fighting their subservient status in Thai society, they have yet to be

\footnotetext{
${ }^{129}$ Falk, p. 49.

${ }^{130}$ Ibid.
} 
fully acknowledged under Thai law and the Buddhist Sangha. The Nun's Bill in1996 and the bill in 2007 have sought to establish these rights for the Thai mae chis.

The Nun's Bill of 1996 was lobbied by mae chi Kanitha Wichiencharoen, who promoted the welfare and promotion of women's rights in Thailand. The main purpose addressed by the bill was to grant that the nuns be considered their own governing body under both Thai and Buddhist law. That body would have absolute authority to appoint and disrobe members, as well as to provide them with full rights in allocating budgetary funding.

Surprisingly, even though mae chi Kanitha wanted only the best for the nun community, many in the mae chi community opposed her efforts. Somswadi states that mae chis "felt that in exchange for legal status, they would have to sacrifice the equality of their sisterhood and their work flexibility, to be governed by an autocratic bureaucracy."131 Others in the Thai Mae Chi Institute also felt that the new laws would hurt them, not help them. Due to many loopholes in Kanitha's proposed bill, it did not pass in 1996, but a new more organized bill has been recently introduced.

The latest bill is now being considered by the Thai National Legislative Assembly, and is described as follows:

the bill accepts the status of nuns as Buddhist priestesses for the first time on the condition they must be ordained by an abbot or a person authorized by an abbot. Any house of nuns will be under the jurisdiction of a temple, an abbot or a Buddhist juristic entity. The bill also requires the state to support the development of Buddhist nuns. The bill calls for the formation of a government panel to promote and protect Buddhism. ${ }^{132}$

131 Somswadi, p. 72.

132 Manop Thip-Osod, "Thailand's to Consider Bill on Offenses to Buddhism." Bangkok Post (October 24, 2007). 
The important aspect of this new bill is that it recognizes the legitimacy of nuns. Whether this refers to the Thai mae chi or to the fully ordained bhikkhuni is yet to be decided. Either way, passage of the bill would represent a giant step for the advancement of ordained women in Thailand. However, a major issue to consider is that the mae chi would need to be under the direct supervision of a temple and therefore could lose some of the autonomy they have developed in recent decades.

As we have seen, the five to nine-precept mae chis have undergone significant discrimination by Thai society, but have recently been able to improve their status. With the consecration of the first Buddhist school and later a separate university for girls, the status of the Thai mae chi is surely changing. For a consideration of how education is helping to elevate the mae chi, let us now turn to a discussion of the Thammacarini Witthaya School and the Mahapajapati Theri College.

The Thammacarini Witthaya School

The Thammacarini Witthaya School opened in 1990 in central Thailand as a selfgoverning Buddhist nunnery. It was established as the first Buddhist school offering free secondary education to girls and mae chis. The funding to start the school came from many donors, including other mae chis and even a highly influential monk, Luang Po Im, from Wat Somanas in Bangkok. The donors all agreed that impoverished girls and women from poor, rural families needed access to education. Building a Buddhist school for girls helps provide opportunities similar to those offered to underprivileged boys through the Buddhist monastic system. Only girls who have already completed six years of compulsory primary education are welcome at the school. Thammacarini Witthaya may be the only chance for many of these poor girls to continue their academic studies. 
The curriculum offered at the school covers three secular grades in only two years. Six basic subjects are covered: English, Thai, mathematics, social studies, science, and Buddhism. In addition, the girls learn vocational skills such as typing, sewing, weaving, crocheting and flower making. The girls also study cooking and gardening, which helps the school cut costs, while at the same time teaching the girls important skills.

In 1990, twenty-two girls and twenty-three mae chi were studying at Thammacarini Witthaya. Now there are about sixty students and more than fifty thammacarini (lay dhamma students) along with fifty mae chi living at the nunnery. ${ }^{133}$ Even more students would like to attend, but the facility needs to be expanded and additional funding would be necessary to accommodate the changes. Currently over one hundred students have graduated from the school with many pursuing university education at one of Thailand's open universities. However, the chance for poor Thai girls and mae chis to attend inexpensive Buddhist schools does not stop with Thammacarini Witthaya.

With the creation of the Mahapajapati Theri College in 2001, mae chis were given access to a religious university education which previously was restricted to monks. The school was founded by the help of mae chi Kanitha Wichiencharoen, along with her organization, the APSW, and the guidance of the Thai Mae Chi Institute. A proposal was sent to a popular Buddhist monk's college, Mahamakut University, in 1998 and received approval and affiliation through its faculty of Religion and Philosophy the following year. Two years later, Mahapajapati Theri College became fully operational, and in 2002, it was brought under the royal patronage of the Sangharaja. As an expression of his support,

${ }^{133}$ Falk, p. 66-67. 
the Sangharaja graciously awarded a substantial donation toward the construction of a meditation hall at the college.

The low-tuition school focuses on Buddhism, but allows its students to select majors in Religion and Philosophy, Teacher Certification, or Social Work. A wide range of basic college-level courses are also offered in English, Computer Science, Psychology, and Statistics. The university is open to both mae chi and non-ordained women, as the school's founders were aware that some general female students, who are interested in Buddhism although not ordained, may be interested in attending.

Although the Thai mae chi are still without mention in Thai law and Buddhist scripture, they will continue to work on furthering their status. Things may change significantly for them if the bill proposed in October 2007 is passed in the legislative assembly. In spite of all the progress remaining, goals for the future of the Thai mae chi movement include: (1) being formally acknowledged by the Thai Constitution, thus giving the mae chis access to privileges granted ordained bhikkhus; (2) their acceptance as ordained peoples by the Thai Buddhist Sangha; and (3) an overall acceptance of their religious status by Thai society, allowing them to shatter the stereotypes of "heart-broken women" and "false nuns." Ultimately, the goal of the Thai mae chi is to be taken seriously for their religious pursuits and to be respected significantly more than in the past. 


\section{CHAPTER SIX}

\section{THE BHIKKHUNI STRUGGLE IN THAILAND}

\section{The Lack of a Bhikkhuni Sangha}

We have examined the mae chi role in Thai culture and described how mae chis are both hindered and empowered by Thai Buddhism in the present day. We will now consider the alternative ordination path for women, the bhikkhuni (311 precept female monk). ${ }^{134}$ The historical record shows that the Bhikkhuni Sangha (community of ordained females) never developed in Thailand as it did in its Theravada neighbors, India and Sri Lanka. ${ }^{135}$ This is due in part to the fact that the lineage never reached Thailand during its spread south from India to Sri Lanka, and north to China. During the eleventh and twelfth centuries, political turmoil and war broke out in Sri Lanka resulting in the disappearance of both male and female sanghas from the region. ${ }^{136}$

Previously in Thailand, there have only been three of the four pillars declared to fulfill a complete Buddhist Sangha as authorized by Gautama Buddha during the fifth century BCE. He prescribed that a Buddhist Sangha consist of ordained men (bhikkhu) and women (bhikkhuni), as well as lay men (upasakāa) and lay women (upāsikā). Due to the discrimination Thai women have faced throughout the patriarchal history of the

${ }^{134}$ As previously mentioned in Chapter One, I refer to the bhikkhunis as female monks rather than ordained nuns, so as not to confuse them with the mae chi.

${ }^{135}$ Sri Lanka is the only Southeast Asian Theravada country to have reestablished a Bhikkhuni Sangha today.

136 The Bhikkhu Sangha (community of ordained male monks) was reestablished with the help of Burmese and Thai monastic lineages, but the Bhikkhuni Sangha did not reappear until 1998, with the help of the Chinese Bhikshuni Sangha and the international organization Sakyadihita, "Daughters of the Buddha." 
country, the fourth pillar has never been allowed, legitimated, or popularly accepted despite attempts in two previous waves to alter the Theravada Buddhist mindset of the country.

In addition to political forces, Buddhist thought plays a role in barring women from full ordination. Although the Buddha himself ordained women and accepted them into monastic life, in the Thai Theravada Buddhist lineage, women are deemed unable to receive full ordination. There seems to be a contradiction here, since in the Buddha's time, there needed to be four pillars, while today, even though some women care to reintroduce the Bhikkhuni Sangha in Thailand, the Buddhist organization and state religion apparatus insist it cannot be established. This is the main issue that plagues the bhikkhuni ordination debate. Monks and the Thai government argue that any order of nuns with the authority to provide the bhikkhuni lineage became extinct in the eleventh century CE. Without a legitimate unbroken lineage it is argued, a Bhikkhuni Sangha cannot be developed in Thailand. Yet because in Sri Lankan history there was a legitimate Bhikkhuni Sangha at one time, Buddhists have been successful in reintroducing it back into that society. However, this was not done quickly, quietly, or easily. The Bhikkhuni Sangha in Sri Lanka is still highly scrutinized and under the watchful eye of the Bhikkhu Sangha, and it is not accepted without some degree of prejudice.

This recent development in Sri Lanka was only possible with the help of other international Buddhist women's organizations, including Mahayana institutions from East Asia. These East Asian Mahayana Bhikshuni ${ }^{137}$ orders were used to legitimate the

\footnotetext{
${ }^{137}$ The spelling for Theravada Buddhist nuns is bhikkhuni and for the Mahayana tradition is bhikshuni.
} 
Theravada tradition in Sri Lanka because their lineage can be traced back to India and Sri Lanka, which were historically Theravada Buddhist countries. This is how Sri Lanka has been able to get around the issue. On the other hand, Thai Buddhists have not been able to follow suit, since they have never historically had a Bhikkhuni Sangha, and therefore the Buddhist Council and Bhikkhu Sangha are much stricter and less flexible with this rule.

The argument against bhikkhuni ordination in Thailand is twofold. First, the monastic ordination procedures for women say that at least five bhikkhus and five bhikkhunis must be present in order to admit a woman into the Sangha. Thai officials say that since the country does not have an official Bhikkhuni Sangha, ordination is impossible. However, leading proponents today for the legitimation of the women's movement in Thailand suggest that this is not an obstacle, since Sri Lanka currently has more than five bhikkhunis. With their help, Thailand could ordain women into the order. Nevertheless, Thai Buddhist officials deny the Sri Lankan lineage because they believe it does not represent a pure and unbroken succession of bhikkhuni ordination. ${ }^{138}$ Therefore, any ordination performed in Sri Lanka would not be recognized under Thai law.

However, it is argued that the Bhikkhuni Sangha is still alive and the transmission of the lineage has never been interrupted. ${ }^{139}$ Hence, women in the Theravada tradition can be ordained as bhikkhuni with the help of the Bhikshuni Sangha in China, Taiwan, or Korea. Unfortunately, the Thai Theravadins claim that all those Bhikshuni Sanghas are of

${ }^{138}$ This point will be refuted in a later section.

${ }^{139}$ See Karma Lekshe Tsomo, "Mahapajapati Legacy: The Buddhist Women's Movement an Introduction," in Women and World Religions, ed. Lucinda Joy Peach, 7786 (Upper Saddle River, NJ: Prentice Hall, 2000), p. 81. 
the Mahayana branch, and therefore not acceptable. Insisting on always preserving the purity of its lineage and its teachings, the Thai Theravadin branch rejects any interference from other schools. As a result, women have lost their right to undergo the bhikkhuni lifestyle of formal and proper ordination in most of Southeast Asia.

What actually happened to the bhikkhuni lineage in history? We must first go back to the tenth century CE, when the Muslim Turk invasion and attack caused the collapse of Buddhism in India, and with it, its monastic tradition. The Theravada Bhikkhuni Sangha in Sri Lanka lasted for about another hundred years, only to collapse in the eleventh century CE. Later, the Hindu Tamil Chola invaders from Southern India attacked and conquered the capital city of Sri Lanka in $1017 \mathrm{CE}$. This event caused bhikkhus and bhikkhunis to become extinct, as many were forced to flee the country. ${ }^{140}$ As a result, the two sanghas disappeared. In 1086, King Vijayabahuthe was successful in expelling the invaders, and was well known for finding authentic Sinhalese bhikkhus in nearby Burma. King Vijayabahuthe brought them back to Sri Lanka and was able to reestablish the Bhikkhu Sangha there. Afterward, when conflicts and famine occurred to again destroy the monastic order, Sri Lanka requested a favor from bhikkhus in Burma by asking them to give ordination to the bhikkhus in Sri Lanka. In $1753 \mathrm{CE}$, the order of Sri Lankan monks died out once more; this time, Siam (now Thailand) was asked to send their bhikkhus in order to provide for Sri Lankan ordination.

On the bhikkhuni side of history, the Buddha himself ordained women in roughly $600 \mathrm{BCE}$. Sri Lanka received the ordination lineage from India four hundred years later

${ }^{140}$ Damien Keown, Buddhism: A Very Short Introduction (New York: Oxford University Press, 1996), p. 70-71. 
in 200 BCE. Next, China came into the picture and received the lineage from Sri Lanka in $433 \mathrm{CE}$ and later ordained women in Japan, Vietnam, Korea, and Taiwan based on the original line of transmission. As noted earlier, centuries later, in the tenth and eleventh centuries in India and Sri Lanka, both sanghas died out. However, in 1998, only ten years ago, Sri Lanka received the lineage from China, which China had once received from Sri Lanka, thereby reestablishing a Bhikkhuni Sangha from its own direct line.

It is well documented in the Sri Lankan Theravada Buddhist tradition that Ceylon (Sri Lanka) would be the place where the purest form of Buddhism would be preserved. This is taken from the Mahavamsa Sri Lankan chronicle that says the Buddha himself proclaimed this. It is based on legends that he made three visits to Sri Lanka, and by extension in spirit to Burma and Thailand. This same view is also found in a Mahayana text titled the Lankavatara Sutra. However, while the Mahayana school accepts the fact that the purest form of original Buddhism is preserved in Sri Lanka, Mahayanists claim themselves to be the most advanced Buddhist school, creating a polemical contest that affects the relationship between the Buddhist schools. ${ }^{141}$

Although Theravadins and Mahayanists are both Buddhist, the Thai tradition feels superior to the Mahayana School. In an observation made in 2007 at the Thai Wat Buddharangsi of Miami, the head abbot shared with the group the story of a recent visit he had made to Thailand. During his visit, he attended a Buddhist conference at a local Thai Theravada Buddhist temple where foreign Mahayana monks from Japan and Korea

\footnotetext{
${ }^{141}$ For additional reading see Wilhem Geiger trans., The Mahavamsa or Great Chronicle of Ceylon (New Delhi: Asian Educational Services, 1912); and Floin Girispescu Sutton, Existence and Enlightenment in the Lankavatara Sutra (Albany, NY: State University of New York Press, 1991).
} 
were present. He spoke about how the Japanese monks criticized the Thai monks for smoking, and how the Thai monks rebutted by accusing the Japanese monks of breaking their vows of celibacy when they act as both Japanese Shinto priests and Buddhist monks (a common phenomenon in Japan). This simple story suggests that the schools do not follow one set of principles and also depicts how there is often a heated debate over proper Vinaya practice when the members of each school interact.

Although the Thai Buddhist abbot of Wat Buddharangsi of Miami suggested that Buddhism should be free from these distinctions, the debate continues. Theravada monks, including those from Thailand, do acknowledge the other schools of Buddhism and their bhikkhus, and allow them to reside in their monasteries and even hold dhamma talks or Buddhist discussions on their premises. However, one school may find their practices challenged or debated by the other. Part of this debate involves the status of a Bhikkhuni Sangha in Thailand, in which the Mahayana Buddhist tradition is claimed to be inferior and not eligible to be used for legitimation. Three waves of women since the 1920s have attempted to establish a bhikkhuni movement in the kingdom of Thailand based on the lineage history just described. Let us now examine them.

Three Waves of Bhikkhuni Activism in Thailand

The root of the modern fight for bhikkhuni ordination began in the late 1920s with two young Buddhist sisters, Sara and Chongdi Bhasit. The movement to introduce bhikkhunis which traditionally did not exist in Thai Theravada Buddhism was instigated by the political yet unconventional figure, Narin Klung, also known as Narin Bhasit and 
the father of Sara and Chongdi Bhasit. ${ }^{142}$ It was through the sisters' relationship with this powerful figure that they were able to introduce the issue of bhikkhuni ordination into modern Thai history. In 1928, they fought aggressively for the revival of a bhikkhuni order in Thailand, and set out to gain an equal right for all women to obtain full ordination in the Theravada tradition as once granted by the Buddha himself.

Due to Klung having been a highly respected government official, the movement received a great deal of attention from the government, the Sangha, and the media, not all of which was necessarily positive for the overall cause. The attention was due to the fact that after Klung's government service had ended, he wrote prolifically in opposition to the government and its policies, especially those regarding the close relationship between the Sangha and the state. ${ }^{143}$ By this time, many considered Klung eccentric, and even a bit peculiar, for his direct opposition to matters of the state and the Thai Buddhist institution. Due to the intensity and the controversial aspect of his writings, they were not taken seriously, as the majority of the Thai population began to consider Klung quite foolish, particularly after he wrote a letter of appeal to the king requesting his support and assistance for the higher ordination of women. Some attribute this peculiar behavior to a dramatic downfall in Klung's mental condition, which was understood as a direct effect

${ }^{142}$ Narin Klung was considered unconventional because he deviated from Thai social, political, and religious norms, especially in the way he went about introducing the bhikkhuni into Thai culture.

${ }^{143}$ Klung's position addressed the fact that Thai society was involved more intimately with institutional Buddhism rather than what he felt was true Buddhism: the dhamma. Klung felt the majority of Thai people were being blinded by the state's message of what Buddhism should be. He felt that it was critical for there to be dialogue between Buddhist officials and the laity. He both wrote and fought for this right through his Bangkok based organization the Buddha Borisat Samakhom. See "Outlawed Pages of History." The Nation January 5, 2004. 
of his having spent considerable time in prison. It is not clear whether Klung truly suffered from some kind of mental breakdown, or whether his views were negatively received by society and later branded as the work of a madman. Klung had been thrown in jail several times throughout the late 1920s and early 1930s because of his refusal to shut down his homemade printing company that published and disseminated antigovernment literature, which challenged political as well as religious ideals in Thailand.

Whether crazy or sane, Klung helped to establish an environment for his two daughters and eight other samaneris that should not be underestimated. Through his generous support, (having offered his own home to be used as the first temple for women novices, known as Wat Nariwong), Klung started a struggle that would in later decades gain momentum and even generate global attention.

However, the optimistic father and Buddhist reformer was not as successful as he envisioned since the Supreme Patriarch issued an order in 1928 that forbade any woman to don saffron robes and any bhikkhu to give Sikkhamana, Bhikkhuni, or Samaneri ordination to any Thai woman. The young girls were determined to continue their efforts even after they were thrown in jail for refusing to disrobe. But due to a dramatic act of disapproval that manifested through a violent display of public denunciation when a member of their own community assaulted one of the sisters, the movement came to a crashing halt. ${ }^{144}$

If Klung had not fought so openly and intensely in such an insistent manner for the introduction and acceptance of bhikkhunis during a time when the issue was not so

\footnotetext{
${ }^{144}$ The media response on this issue led the majority of the Thai public to react negatively towards the Bhasit sisters. Even their neighbors began to grow increasingly intolerant of them and their reformist views.
} 
well understood, the order to suppress the bhikkhuni movement by the Supreme Patriarch might not have been issued or adhered to so strictly by the sangha in the present day. If Klung had proceeded slowly and with more caution, perhaps the modern bhikkhuni struggle would not be so difficult today.

On the other hand, there is no doubt that without Sara and Chongdi's father's direct involvement with their movement for bhikkhuni ordination, they would have been able to achieve the level of success they attained. The establishment of a temple for bhikkhunis and the means for continuing their fight were brought on by this privilege of association with their reformist father's approach to revising the Thai Buddhist tradition, as these women were given ordination through Klung's relationship with other tolerant bhikkhus before the Supreme Patriarch's famous order was established. ${ }^{145}$

For the Bhasit sisters, their father's opinion and prolific writing in favor of introducing a Bhikkhuni Sangha were both helpful and hurtful to their overall goal. They were helpful in the sense that they gave the sisters support and provided them with channels, but hurtful because of the responses made by the Supreme Patriarch and other Buddhist authorities due to Klung's oppositional and aggressive stance against the Thai Buddhist institution. Because of this, these young girls were only briefly allowed to participate in this opposition movement, which lasted less than three years in total. Nevertheless, the bhikkhuni movement would be re-awakened twenty-eight years later by another modern female intellectual.

\footnotetext{
${ }^{145}$ Since the ordination of women was so controversial then, the name of the preceptor and monk who ordained the young women is not known.
} 
The next generation of bhikkhuni activism began with Voramai Kabilsingh, an outspoken journalist and humanitarian interested in the improvement of social welfare. Her movement was initiated in 1956 by her acceptance of monastic life and reception of eight precepts, the shaving of the head, and the donning of a light yellow robe.

Traditionally nine precept nuns (mae chi) wore the color of white. Voramai was the first to push the envelope, so to speak, in separating herself from the mae chi by wearing a light yellow robe. In 1960 this was not taken lightly and was viewed by the Buddhist institution as a sign of disrespect against the Bhikkhu Sangha. Her early commitment to the Buddhist faith was visible through her dedication to the construction, management, and maintenance of an orphanage and Buddhist school for girls, which she opened in 1960. This orphanage later served as a Buddhist temple for women, Wat Songdhammakalyani.

Regarding Voramai Kabilsingh's monastic instruction, her preceptor and Buddhist teacher was none other than the abbot of Wat Bowon, Phra Prommuni. Phra Prommuni was an important Buddhist figure in Bangkok, having been directly involved with the ordination process of the current king and for serving as a member of the Buddhist Council of Elders until his death in 1961. Voramai began her practice under Phra Prommuni's tutelage for four years, until her case was surprisingly taken up by the Buddhist Council of Elders and she was formally charged with impersonating a monk. ${ }^{146}$ Through her association with Phra Prommuni, who outspokenly stood up in defense of her wearing a light yellow robe, since it was not in direct conflict with the color of Thai

146 This is considered a federal offense in Thailand. 
bhikkhu robes, she was spared from serving jail time and from losing her orphanage school/temple to the government. ${ }^{147}$

In 1971, she traveled to Taiwan to receive higher ordination from the Mahayana tradition, thus proving her determination and willingness to receive Buddhist precepts. Unfortunately, due to her inability to receive the ordination lineage from the Theravada tradition and from a Bhikkhuni Sangha, the Thai Buddhist institution failed to recognize her. ${ }^{148}$ Although the Taiwanese had a Bhikshuni Sangha, the issue regarding the greater purity of the Theravada lineage over that of the Mahayana arose in the Thai Buddhist Council's inability to identify Voramai as a bhikkhuni. Voramai nevertheless achieved the title of the first bhikkhuni in Thailand through her ability to network and by means of her education and know-how. This allowed her to communicate and establish a connection with a far off movement in East Asia, and enabled her to involve others in her movement, as she was alone in the Thai bhikkhuni struggle. Her association with the Taiwanese Sung San Temple, where others shared her same view that Buddhist women should have the right to bhikkhuni ordination, guided her to secure full ordination proceedings, preceptors, and teachers. Voramai died before Thailand would legitimize a Bhikkhuni Sangha, but her inspiration lives on through the third wave of bhikkhuni activism. She was ninety-six years old at the time of her passing in June 2003.

${ }^{147}$ The school today occupies the temple grounds of Wat Dhammakalyani, and has since been under the direction of the Buddhasavika Foundation and its director Venerable Dhammananda. The Buddhasavika Foundation protects the temple from any outside interference from the government.

${ }^{148}$ We must also keep in mind that the 1928 order has never been lifted. The order denies Thai women the right to higher bhikkhuni ordination. 
Venerable Bhikkhuni Dhammananda, the former Dr. Chatsumarn Kabilsingh, Voramai's only daughter, is today the leading proponent for the legitimation of a Bhikkhuni Sangha and the head of the movement. Having grown up with a role model such as Voramai, Chatsumarn learned early on about the dedication involved in undertaking a monastic life. ${ }^{149}$ The bulk of Chatsumarn's adult life was devoted to the academic pursuit of Buddhism, with special concern for the position of women in Thai culture. Although Dr. Kabilsingh addressed the issue of bhikkhuni ordination in Thailand, she never really considered becoming ordained herself, as she was committed to a weekend practice of Buddhist devotion and meditation and had dedicated the bulk of her academic energies to writing about Buddhism. It was not until she attended a closed conference among feminists at Harvard University in 1983 that it became apparent to her she must come down from the "scholarly ivory tower" to embrace Buddhism on the socially engaged level.

This period marked a crucial turning point for the former professor, as her new awareness led to the publication of a quarterly newsletter titled Yasodhara, ${ }^{150}$ which began in 1984, and to organizing the first International Conference on Buddhist Women, known as the Sakyadhita, in 1987. The newsletter has been in print for over twenty-three years, and the Sakyadhita has convened successfully for nine sessions, meeting roughly every two years in different international locations. ${ }^{151}$ Chatsumarn considers the "good

${ }^{149}$ Her father was also ordained during his lifetime.

${ }^{150}$ Her mother also published a newsletter out of Wat Songdhammakalyani for thirty two years.

151 The tenth annual conference will be held in Mongolia this summer, July 1-5, 2008. 
reception" she received in 1993 at the Sakyadhita conference in Sri Lanka as the precursor to her requesting higher ordination from the Sri Lankan lineage, which she received eight years later in $2001 .^{152}$ Even though Chatsumarn was ordained by a Theravada lineage, the Thai Buddhist Sangha still refuses to accept her as a full bhikkhuni today. At present, she is the most prominent advocate for the legitimation of a Thai Bhikkhuni Sangha and it is through her leadership that the current strategy has been developed. There are other women being ordained throughout Thailand today, but most have some relationship or communication set up with Venerable Dhammananda.

Current Strategy and Competition with the Mae chi Movement

The latest plan of action for the Thai bhikkhuni movement is based on the continued ordination of strong, educated women. Without determined and eager women, the movement cannot gain momentum, and without educated women, it will never be taken seriously. ${ }^{153}$ One new feature of the bhikkhuni movement is that it is now branching out of Wat Songdhammakalyani, the location out of which Voramai and Chatsumarn Kabilsingh originally worked. The temple is still operational and has roughly two samaneris and two fully ordained bhikkhunis on its premises, but the nationwide

\footnotetext{
152 Taken from an interview with Venerable Dhammananda dated January 28, 2004, conducted by a University of California at Santa Barbara PhD Candidate, Michael Jerryson.

${ }^{153}$ As previously mentioned in Chapter Four, the bhikkhuni movement has been viewed in many circles as a means for decreasing the number of sex trade workers. However, Venerable Dhammananda does not want to ordain recent prostitutes for fear they will harm the purity of the movement. She believes that one day, after the bhikkhuni are fully accepted within Thai culture, women of all trades and educational levels will be able to enjoy temporary bhikkhuni ordination just like men in the country do, although this consideration is very far off.
} 
bhikkhuni movement currently has ordained samaneris (novices) and other bhikkhunis in cities in northern Thailand and inside the capital city of Bangkok.

Although all the women know each other, they did not seek ordination from the same lineages or necessarily have the same overall goals. Regardless, the women share one thing: bhikkhuni higher ordination. With the women working from various locations throughout the country, they hope to attract attention to their cause by educating Buddhist lay followers on their future plans and attempting to win their minds and hearts, one Buddhist village at a time.

Currently, there are fourteen samaneris ordained under the Theravada lineage in locations throughout Thailand, and six fully ordained bhikkhunis. There are also over two hundred bhikshunis ${ }^{154}$ ordained from the Mahayana tradition working under Venerable Ambika in Bangkok. However, they live and work in mostly Chinese shrines and vegetarian houses near the capital, and their services are said to be limited to the Chinese sectors of Thai society.

Although the bhikkhuni movement is making progress, bhikkhunis do have some competition with the alternative spiritual path for women: the Thai mae chi. It is said that Thai mae chi Kanitha, the founder of the Association for the Promotion of the Status of Women (APSW) and leading proponent for the advancement of women's rights, especially mae chi rights,

refrained from advocating full ordination for nuns, so as to not jeopardize her work for the mae chis....she believed that once the mae chis gained wide social

${ }^{154}$ See Thai Bhikkhuni Org contributors, "Bhikkhuni Population," http://www.thaibhikkhunis.org/eng/index.php?option=com_content\&task=view\&id=38\& Itemid=21 (accessed Feb. 21, 2008). 
acceptance and their status became stable, the institution of the Bhikkhuni Sangha would naturally follow. ${ }^{155}$

It is also noted that Chatsumarn Kabilsingh once requested that mae chi Kanitha become ordained as a bhikkhuni before she herself undertook the precepts. ${ }^{156}$ But Kanitha was steadfast in her decision to work exclusively for the mae chi movement.

Another view is that of Thai religious scholar Puntarigvivat, "if the Bhikkhuni institution existed in Thailand, it would eventually replace the mae chi and would greatly raise women's status at the core of Thai culture." 157 Thai mae chi Prathin issued a rebuttal saying:

I believe we should have diverse organizations for different needs. The mae chi status can provide a refuge for poor, rural women who may know nothing about Dhamma and are not certain about their life's goals. They are definitely not ready to become a bhikkhuni. But they can try studying Dhamma and maintain the precepts as a mae chi. ${ }^{158}$

In addition, the research findings of Thai mae chi scholar Monica Lindberg Falk suggest that mae chis, in general,

are not struggling for full ordination. Although a few of the mae chis I have interviewed state that they would be interested in receiving full ordination if it were possible in Thailand, most report that they would rather develop themselves spiritually as mae chis. ${ }^{159}$

155 See Karma Lekshe Tsomo, "Khunying Kanitha," in Buddhist Women and Social Justice, ed. Karma Lekshe Tsomo, 173-191 (Albany, NY: State University of New York Press, 2004), p. 188.

156 Somswasdi, p. 72.

157 Ibid., p. 73.

158 Ibid.

159 Falk, p. 46-47. 
Perhaps there could be more than one position for Buddhist women in Thai culture. However, when both movements are seeking advancement at the same time, it creates a difficult situation for the overall acceptance and legitimation of either position in light of modern Buddhist politics. The relationship between the bhikkhuni and mae chi movements can be viewed as one of opposition because they are in essence competing for similar, if not identical, resources from the Buddhist monastic community, Thai government, and the Thai lay population. It can then be concluded that they are somewhat locked into adversarial stances due to the socio-political situation of Buddhist affairs in the Thai kingdom.

\section{Conclusions}

Throughout the course of this study, the status of women in Buddhism has been examined from various angles, illustrating how this is a controversial topic in contemporary Thailand. While late modernity has begun to change the attitudes of the highly educated in Thai society, the progress on gender issues is still moving rather slowly, with Buddhism envisioned as a part of the solution for the future. Despite its problematic history, the dominant religion of the kingdom is viewed, by some, as a means for empowering women to find a spiritual outlet for the advancement of women's rights through the mae chi and bhikkhuni alternatives. However, with the social problem of prostitution pervading Thai culture and creating yet another merit-making opportunity for poor, uneducated, rural, young girls, popular Thai Buddhism finds itself in the midst of a very delicate situation.

Given the treatment of gender in Thai society detailed in Chapter Two, the role Thai women play in contemporary Thailand is vastly improved compared to the 
conditions women held during the early-modern period. On the other hand, in some respects, at least for the northern parts of Thailand which originally practiced a matrilineal system, some women may be viewed as having been denied their cultural freedoms and privileges. With regard to the religious system in the country, we saw how Buddhism is intricately connected with the Thai government, thus holding a privileged position in both religious and non-religious sectors of Thai society.

Chapter Three located the dynamics of the sex trade in terms of historical and contemporary analyses by highlighting how both the Thai economic boom and the HIV/AIDS crisis can be attributed to the infamous yet highly marketed foreign and local sex trade. The condition of female prostitutes was also considered, as there are far more females than males involved in prostitution.

Chapter Four illustrated Buddhism's connection to the sex trade, and the relationship was seen to depend in part upon the attainment of Buddhist "merit" for donations to temples of funds earned from the sex trade. Also, many rural families allow their young girls to be sold into the sex trade as a means of obtaining the money needed to supply their oldest son with a Buddhist bhikkhu ordination; this represents one way popular Thai Buddhism can be seen in relation to prostitution. A third connection between Buddhism and the sex trade includes women choosing to enter the sex trade so they can send money back to their families as a form of filial piety. In any case, the money generated from prostitution is viewed as an acceptable way to generate "merit" in the Thai Buddhist system. The way women are viewed both negatively and positively through the Buddhist texts was also sketched in this chapter. 
In the final chapters of this thesis, the religious options of the Thai mae chi and bhikkhuni were examined, and a history of each movement's important contributions was brought to light. For the mae chis, the creation of the Thai Mae Chi Institute, the first Buddhist school, Thammacarini Witthaya, and the first Buddhist college, Mahapajapati Theri, play a significant role in helping to elevate their status in Thai society. The bhikkhuni movement's strategy of branching out from one main location to ordain women throughout the country, as opposed to just one city, thus promoting women's higher ordination in all parts of Thailand, is proving to be effective. However, the two positions of bhikkhuni and mae chi are competing for many of the same resources from the Thai government, the lay Buddhist community, and the Bhikkhu Sangha.

In conclusion, although women in Thailand are considered to have an above average status compared to some other Asian countries, the majority of them are still significantly lacking in the area of education. As many poor young boys can attest, the Buddhist monastic system offers them a source for attaining formal education and a way out of an impoverished lifestyle in Thailand. Unfortunately, Thai women both historically and currently have been denied that privilege. Since Buddhism is the dominant religion in Thailand, it has been called upon to address these issues and at least attempt to find a better outlet for women. It is difficult to find a solution because Buddhism is said to contribute to the low status of women by how it defines them with respect to the Buddhist scriptures and in relation to traditional Thai cultural beliefs. Buddhism can also be considered liable for not providing the same religious outlets for women with which Thai men are endowed. 


\section{REFERENCES}

Aronson, Harvey B. Love and Sympathy in Theravada Buddhism. Delhi: Motilal Banarsidass Publishers, 1989. 2004. . Buddhist Practice on Western Ground. Boston: Shambhala Publications,

Barme, Scot. Woman, Man, Bangkok: Love, Sex and Popular Culture in Thailand. Lanham, MD: Rowman \& Littlefield Publishers, 2002.

Becher, Jeanne, ed. Women, Religion and Sexuality: Studies on the Impact of Religious Teachings on Women. Philadelphia, PA: Trinity Press International, 1990.

Bishop, Ryan and Lillian S. Robinson. Night Market: Sexual Cultures and the Thai Economic Miracle. New York: Routledge, 1998.

Boonchalaksi, Wathinee and Philip Guest. "Prostitution in Thailand," In The Sex Sector: The Economic and Social Bases of Prostitution in Southeast Asia, edited by Lin Leam Lim. Geneva: International Labour Office, 1998.

Brock, Rita Nakashima and Susan Brooks Thistlethwaite. Casting Stones: Prostitution and Liberation in Asia and the United States. Minneapolis, MN: Fortress Press, 1996.

Brown, Sid. The Journey of One Buddhist Nun: Even Against the Wind. Albany, NY: State University of New York Press, 2001.

Bullough, Vern L. Women and Prostitution: A Social History. New York: Prometheus Books, 1987.

Cabezon, Jose Ignacio, ed. Buddhism, Sexuality, and Gender. Albany, NY: State University of New York Press, 1992.

Chondron, Thubten, ed. Blossoms of the Dharma: Living as a Buddhist Nun. Berkeley, CA: North Atlantic Books, 1999.

Christ, Carol P. and Judith Plaskow, eds. Women Spirit Rising: A Feminist Reader in Religion. New York: Harper San Francisco, 1992.

Cooey, Paula M., ed. After Patriarchy: Feminist Transformations of the World Religions. New York: Orbis Books, 1991.

Davids, Rhys, trans. Psalms of the Early Buddhists I. Oxford: Pali Text Society, 1994. 
Davids, T.W. and Hermann Oldenberg, trans. "Vinaya Texts Part III The Kullavagga IVXII." In The Sacred Books of the East, edited by F. Max Muller. Delhi: Motilal Banarsidass Publishers, 1965.

Ekachai, Sanitsuda. “A Nun's Life has Limited Appeal.” Bangkok Post. http://www.budsas.org/ebud/ebdha220.htm (accessed January 21, 2008).

Enloe, Cynthia H. Bananas, Beaches \& Bases: Making Feminist Sense of International Politics. Berkeley, CA: University of California Press, 1990.

Eppsteiner, Fred, ed. The Path of Compassion: Writings on Socially Engaged Buddhism. Berkeley, CA: Parallax Press, 1985.

Falk, Monica Lindberg. "Thammacarini Witthaya: The First Buddhist School for Girls in Thailand." In Innovative Buddhist Women: Swimming Against the Stream, edited by Karma Lekshe Tsomo., 61-71. Richmond, UK: Curzon Press, 2000.

. Making Fields of Merit. Copenhagen: NIAS Press, 2007.

. "Women in Between." In Women's Buddhism, Buddhism's Women, edited by Ellison Banks Findly, 37-57. Boston, MA: Wisdom Publications, 2000.

Faure, Bernard. The Power of Denial: Buddhism, Purity and Gender. Princeton, NJ: Princeton University Press, 2003.

Findly, Ellison Banks. Women's Buddhism, Buddhism's Women. Somerville, MA: Wisdom Publications, 2000.

Geiger, Wilhem, trans. The Mahavamsa or Great Chronicle of Ceylon. New Delhi: Asian Educational Services, 1912.

Gross, Rita M. Buddhism After Patriarchy: A Feminist History, Analysis, and Reconstruction of Buddhism. Albany, NY: State University of New York Press, 1993.

. "The Householder and the World-Renunciant: Two Modes of Sexual Expression in Buddhism." In Marriage Among the Religions of the World, edited by Arlene Anderson Swidler, 115-136. New York: The Edwin Mellen Press, 1990.

"Feminist Revalorization of Buddhism." In Feminism and World Religions, edited by Arvind Sharma and Katherine K. Young, 78-109. Albany, NY: State University of New York Press, 1999.

Hare, E. M., trans. The Book of Gradual Sayings Vol. IV. Oxford: Pali Text Society, 1995. 
Heine, Steven. Zen Skin, Zen Marrow: Will the Real Zen Please Stand Up? New York: Oxford University Press, 2008.

Hitchcock, Michael, Victor King and J.G. Michael Parnwell, eds. Tourism in SouthEast Asia. London: Routledge, 1993.

Horner, I. B. Women Under Primitive Buddhism. Delhi: Motilal Banarsidass Publishers, 1930.

Ishii, Yoneo. Sangha, State and Society: Thai Buddhism in History. Translated by Peter Hawkes. Honolulu, HI: University of Hawaii Press, 1986.

Jackson, Peter A. and Nerida M. Cook, eds. Genders \& Sexualities in Modern Thailand. Chiang Mai, Thailand: Silkworm Books, 1999.

Jeffrey, Leslie Ann. Sex and Borders: Gender, National Identity and Prostitution Policy in Thailand. Vancouver: UBC Press, 2002.

Jones, Ken. The New Social Face of Buddhism: A Call to Action. Boston, MA: Wisdom Publications, 2003.

Kabilsingh, Chatsumarn. Thai Women in Buddhism. Berkeley, CA: Parallax Press, 1991. . The Bhikkhuni Patimokkha of the Six Schools. Bangkok, Thailand: Thammasat University Press, 1991.

. Towards Ordination. Nakhonpathom, Thailand: Wat Songdhammakalyani, 2000 .

Kaiser, Henry J. “Thailand's HIV/AIDS Treatment, Prevention Programs Should Serve as Model for Other Countries, Report Says."

www.thebody.com/content/news/art7905.html (accessed February 5, 2008).

Kanabus, Annabel and Jenni Fredrikson. "The History of HIV and AIDS in Thailand." www.avert.org/aidsthai.htm (accessed February 3, 2008).

Katz, Nathan. Buddhist Images of Human Perfection. Delhi: Motilal Banarsidass Publishers, 1989.

. "Buddhism and Politics in Sri Lanka and Other Theravada Nations Since 1945." In Movements and Issues in World Religions: A Sourcebook of Developments Since 1945, edited by Charles Wei-hsun Fu and Gerhard E. Spiegler, 157-175. New York: Greenwood Press, 1987. 
Keown, Damien. Buddhism: A Very Short Introduction. New York: Oxford University Press, 1996.

Keyes, Charles F. The Golden Peninsula: Culture and Adaptation in Mainland Southeast Asia. Honolulu, HI: University of Hawaii Press, 1995.

Khuankaew, Ouyporn. "Feminism and Buddhism: A Reflection through Personal Life and Working Experience." http://www.bpf.org/tsangha/ouyporn.html (accessed December 10, 2007.

Kirsch, Thomas. "Buddhism, Sex Roles and the Thai Economy." In Women of Southeast Asia: Monograph Series on Southeast Asia Occasional Paper No. 9, edited by Penny Van Esterik, 16-41. Detroit, MI: The Cellar Book Shop, 1982.

Klausner, William J. Thai Culture in Transition: Collected Writings of William J. Klausner. Bangkok, Thailand: The Siam Society, 1997.

Lim, Lin Lean, ed., The Sex Sector: The Economic and Social Bases of Prostitution in Southeast Asia. Geneva: International Labour Organization, 1998.

Mahidol University contributors. "Religion Plays a Very Important Role in Thai Life." http://www.mahidol.ac.th/thailand/religions/relogions.html (accessed November 3, 2007).

Murcott, Susan. First Buddhist Women: Poems and Stories of Awakening. Berkeley, CA: Parallax Press, 1991.

Peach, Lucinda Joy. "Buddhism and Human Rights in the Thai Sex Trade." In Religious Fundamentalism and the Human Right of Women, edited by Courtney W. Howland, 215-226. New York: St. Martin's Press, 1999.

Phongpaichit, Pasuk and Chris Baker. Thailand's Boom and Bust. Chiang Mai, Thailand: Silkworm Books, 1998.

Phongpaichit, Pasuk, Sungsidh Piriyarangsan and Nualnoi Treerat. Guns, Girls, Gambling, Ganja: Thailand's Illegal Economy and Public Policy. Chiang Mai, Thailand: Silkworm Books, 1998.

Puntarigvivat, Tavivat. “A Thai Buddhist Perspective.” In What Men Owe to Women: Men's Voices from World Religions, edited by John. C. Raines and Daniel C. Maguire, 211-237. Albany, NY: State University of New York Press, 2001.

. "Toward a Buddhist Social Ethics; The Case of Thailand." In Crosscurrents Fall 1998, edited by Kenneth Arnold and Joseph Cunneen, 347365. New York: Capital City Press, 1998. 
Queen, Christopher, Charles Prebish and Damien Keown, eds. Action Dharma: New Studies in Engaged Buddhism. New York: Routledge Curzon, 2003.

Rahula, Walpola. What the Buddha Taught. New York: Grove Press, 1959.

Raines, John. C. The Justice Men Owe Women: Positive Resources from World Religions. Minneapolis, MN: Fortress Press, 2001.

Saengtienchai, Chanpen. "Prostitutes are Better than Lovers." In Genders and Sexualities in Modern Thailand, edited by Peter A. Jackson and Nerida M. Cook, 78-92. Chiang Mai, Thailand: Silkworm Books, 1999.

Saipradit, Kularb and Jit Bhumisak. History of Thai Women. Bangkok, Thailand: Somchai Press, 1976.

Satha-Anand, Suwanna. "Looking to Buddhism to Turn Back Prostitution in Thailand." In The East Asian Challenge for Human Rights, edited by Joanne R. Bauer and Daniel A. Bell, 193-211. Cambridge, UK: Cambridge University Press, 1999).

Sharma, Arvind and Katherine K. Young, eds. Feminism and World Religions. Albany, NY: State University of New York Press, 1999.

Skinner, William, G. Chinese Society in Thailand. Ithaca, NY: Cornell University Press, 1957.

Somswasdi, Virada and Alycia Nicholas, eds. A Collation of Articles on Thai Women and Buddhism. Chiang Mai, Thailand: Chiang Mai University Women's Studies Center, 2002.

Sponberg, Alan. "Attitudes toward Women and the Feminine in Early Buddhism." In Buddhism, Sexuality, and Gender, edited by Jose Ignacio Cabezon, 3-36. Albany, NY: State University of New York Press, 1992.

Steinfatt, Thomas M. Working at the Bar: Sex Work and Health Communication in Thailand. Westport, CT: Ablex Publishing, 2002.

Sutton, Floin Girispescu. Existence and Enlightenment in the Lankavatara Sutra. Albany, NY: State University of New York Press, 1991.

Swearer, Donald K. Buddhism in Transition. Philadelphia, PA: The Westminster Press, 1970.

Tannenbaum, Nicola. "Buddhism, Prostitution and Sex." In Genders and Sexualities in Modern Thailand, edited by Peter A. Jackson and Nerida M. Cook, 78-92. Chiang Mai, Thailand: Silkworm Books, 1999. 
Tantiwiramanond, Darunee and Shashi Pandey. By Women, For Women: A Study of Women's Organizations in Thailand. Pasir Panjang, Singapore: Institute of Southeast Asian Studies, 1991.

Thai Bhikkhuni Org contributors. http://www.thaibhikkhunis.org/eng/index.php?option=com_content\&task=view\&i $\mathrm{d}=38 \&$ Itemid=21 (accessed Feb. 21, 2008).

Thip-Osod, Manop. “Thailand's to Consider Bill on Offenses to Buddhism.” Bangkok Post Oct. 24, 2007.

Thitsa, Khin. "Nuns, Mediums and Prostitutes in Cheingmai: A Study of Some Marginal Categories of Women." In Centre of South-East Asian Studies, Occasional Paper No. 1: Women and Development in South-East Asia I, edited by Khin Thitsa and Signe Howell, 3-33. Kent, UK: University of Kent at Canterbury Press, 1985.

Troung, Thanh-Dam. Sex, Money and Morality: Prostitution and Tourism in South-East Asia. London: Zed Books Limited, 1990.

Tsomo, Karma Lekshe, ed. Sakyadhita: Daughters of the Buddha. Ithaca, NY: Snow Lion Press, 1998.

, ed. Buddhist Women and Social Justice: Ideals, Challenges, and Achievements. Albany, NY: State University of New York Press, 2004.

, ed. Buddhist Women Across Cultures: Realizations. Albany, NY: State University of New York Press, 1999.

. "Mahapajapati Legacy: The Buddhist Women's Movement an Introduction." In Women and World Religions, edited by Lucinda Joy Peach, 7786. Somerville, NJ: Prentice Hall, 2000.

Van Esterik, John. "Women Meditation Teachers in Thailand." In Women of Southeast Asia: Monograph Series on Southeast Asia Occasional Paper No. 9, edited by Penny Van Esterik, 42-54. Detroit, MI: The Cellar Book Shop, 1982.

Van Esterik, Penny. "Laywomen in Theravada Buddhism." In Women of Southeast Asia: Monograph Series on Southeast Asia Occasional Paper No. 9, edited by Penny Van Esterik, 55-78. Detroit, MI: The Cellar Book Shop, 1982. . Materializing Thailand. Berg, UK: Oxford, 2000.

Walker, Dave and Ehrlich, Richard S. Hello My Big Big Honey! San Francisco, CA: Last Gasp of San Francisco, 2000. 
Ward, Tim. What the Buddha Never Taught. Berkeley, CA: Celestial Arts, 1990.

Wilson, Ara. The Intimate Economies of Bangkok: Tomboys, Tycoons and Avon Ladies in the Global City. Berkeley, CA: University of California Press, 2004.

Woodward, F. L. trans., The Book of Gradual Sayings. (Anguttata Nikaya) Vol. I-V London: London Pub. for the Pali Text Society of Oxford University Press, 1932-1936. 